\title{
BOILERPLATE NO CONTEST CLAUSES
}

\author{
DAVID HORTON* \& REID KRESS WEISBORD**
}

I

INTRODUCTION

"If any beneficiary under this Will in any manner, directly or indirectly, contests or attacks this Will or any of its provisions, any share of interest in my estate given to that contesting beneficiary under this Will is revoked ..." ${ }^{11}$ This is a "no contest clause": a provision that disinherits anyone who initiates litigation against the testator's estate plan. ${ }^{2}$

The law has long been ambivalent about no contest clauses. A single judicial opinion can waffle between treating these terms as "favored since they discourage litigation" and "disfavored because they work a forfeiture." Scholars who believe that no contest clauses should be enforced cite the primacy of testamentary freedom, which seeks to facilitate rather than regulate the decedent's intent. ${ }^{4}$ Others claim that no contest clauses must yield to "policies transcending private interests," like keeping the courthouse door open. ${ }^{5}$ States have adopted a rain-

Copyright $@ 2019$ by David Horton \& Reid Kress Weisbord.

This Article is also available online at http://lcp.law.duke.edu/.

* Professor of Law and Chancellor's Fellow, University of California, Davis, School of Law.

** Vice Dean, Professor of Law, and Judge Norma L. Shapiro Scholar, Rutgers Law School. We are grateful to George Thomas for his generous financial support, to Neil Horton, Menesh Patel, and Shayak Sarkar for helpful comments, and to John Coyle for his comments and for inviting us to participate in this issue of Law and Contemporary Problems.

1. Last Will and Testament of Louise W. Chin at 2, In re Estate of Chin, No. RP09439753 (Cal. Super. Ct. Mar. 6, 2009) [hereinafter Chin Will].

2. Although no contest provisions are also sometimes called "in terrorem" provisions, we do not use this phrase. As we discuss infra notes 71-72 and accompanying text, courts employ "in terrorem" as a shorthand for the conclusion that a particular term is not enforceable because the testator only inserted it "to frighten the legatee into compliance." Moskowitz v. Federman, 51 N.E.2d 48, 54 (Oh. Ct. App. 1943). Thus, referring to no contest clauses as "in terrorem" clauses is confusing.

3. Estate of Watson, 223 Cal. Rptr. 14, 16 (Ct. App. 1986); cf. Olin L. Browder, Jr., Testamentary Conditions against Contest Re-examined, 49 COLUM. L. REV. 320, 320 (1949) (bemoaning "the persistence of over-generalized and undiscriminating analysis in the cases").

4. Martin D. Begleiter, Anti-Contest Clauses: When You Care Enough to Send the Final Threat, 26 ARIZ. ST. L.J. 629, 630-31 (1994); Gerry W. Beyer et. al., The Fine Art of Intimidating Disgruntled Beneficiaries with in Terrorem Clauses, 51 SMU L. REV. 225, 229 (1998) (arguing that no contest provisions "fulfil[] a donor's clearly expressed intentions").

5. Herman F. Selvin, Comment: Terror in Probate, 16 STAN. L. Rev. 355, 364-65 (1964); cf. Olin L. Browder, Jr., Testamentary Conditions against Contest, 36 MICH. L. REV. 1066, 1106 (1938) (asserting that courts should ignore no contest clauses when a beneficiary's petition "relat[es] to the execution of wills or ... the manner or amount of disposition of property, provided the contest is based on probable cause"). 
bow of different regulatory approaches, including enforcing no contest provisions, invalidating them, or ignoring them if a beneficiary had "probable cause" for her lawsuit. ${ }^{6}$

This invited contribution to Law and Contemporary Problems' special issue on The Butterfly Effect in Boilerplate Contract Interpretation examines no contest clauses from a different angle. ${ }^{7}$ We ask whether these provisions are a symptom of a larger pathology in estate planning: a drafting norm in which attorneys rely too heavily on standardized terms without fully ascertaining the testator's informed preferences. Although people are drawn to any tool that can prevent conflict over their estates, it is well known that " $[\mathrm{m}]$ any attorneys include a no contest clause as boilerplate." "Moreover, no contest clauses can have drastic consequences, such as dismembering entire branches of a family tree from an estate plan. In fact, even when they do not apply, their mere presence can force beneficiaries to incur thousands of dollars in attorneys' fees to obtain declaratory relief that it is safe to take a particular action. ${ }^{9}$

We flagged this overarching problem in a previous paper, Boilerplate and Default Rules in Wills Law: An Empirical Analysis. ${ }^{10}$ In that piece, we studied 230 wills from Sussex County, New Jersey, and discovered that they were riddled with stock terms that "sound[ed] authoritative, but ma[de] little sense in context."11 Most of these clauses governed obscure subjects that testators were unlikely to understand, such as the exoneration of liens, the apportionment of taxes, and the division of property among multi-generational classes. ${ }^{12}$ Alarmingly, this language often overrode majoritarian default rules which are designed to fill gaps in wills while remaining faithful to the wishes of most testators. ${ }^{13}$ Thus, we urged courts and lawmakers to reinforce the background principles that govern these non-salient topics by making them sticky, or harder to draft around. ${ }^{14}$

This Article builds on this foundation by reviewing no contest clauses in 457 wills that were probated in Alameda County, California in the late 2000s. ${ }^{15} \mathrm{We}$ show that testators and their lawyers overuse no contest provisions. Indeed, these

6. See infra notes 73-80.

7. The "butterfly effect' in boilerplate contact interpretation" is the impact "that a single interpretive decision can have on the interests of far-flung parties not involved in the litigation at hand." John F. Coyle, Interpreting Forum Selection Clauses, 104 IOWA L. REV. 1791, 1797 n.17 (2019).

8. Donna R. Bashaw, Are in Terrorem Clauses No Longer Terrifying? If So, Can You Avoid PostDeath Litigation with Pre-Death Procedures?, NAELA J., 2006, at 349, 351.

9. See infra notes 167-178 and accompanying text.

10. Reid Kress Weisbord \& David Horton, Boilerplate and Default Rules in Wills Law: An Empirical Analysis, 103 IOWA L. REV. 663, 663 (2018).

11. Id. at 668 .

12. Id.

13. See id.

14. See id. at 668-69.

15. As we discuss in further depth infra note 135, we focus on wills from California, rather than New Jersey, for two reasons. First, no contest clauses were far more common in the Golden State than the Garden State. Second, because California's approach to no contest clauses changed during our research period, we can examine how testators and their attorneys responded. 
terms appear in nearly seventy percent of the wills in our sample, including many estates in which there is no realistic possibility of discord. For example, the clause in the first lines of this Article comes from the will of a deceased Alameda County resident named Louise Chin. ${ }^{16}$ One can hardly fault Chin for taking precautions against litigation. Yet Chin also named her son Gordon sole beneficiary and executor. ${ }^{17}$ Thus, the only person to whom the no contest provision applied was assuredly not going to challenge the instrument or the management of the estate. At the same time, the provision could have dissuaded Gordon from taking benign steps like asking the court to clarify an ambiguity in the will or to determine whether property belonged to the estate or was held in joint tenancy. ${ }^{18}$ Therefore, we conclude that some no contest provisions are intent-thwarting boilerplate.

We then offer evidence that sticky default rules can help combat this problem. In 1994, the California Supreme Court decided Burch v. George, which interpreted a no contest clause expansively..$^{19}$ In 2001, the California legislature responded to concerns that testators did not appreciate the capaciousness of no contest clauses under Burch by passing Probate Code section $21305 .{ }^{20}$ This statute declares that certain types of lawsuits, such as creditor's claims, and instruments, like codicils, do not trigger contest penalties unless the testator explicitly directs otherwise. ${ }^{21}$

This choice architecture makes section 21305 a sticky default: it nudges testators toward accepting a favorable background principle by increasing the cost and effort required to opt out. Indeed, the law incorporates the two most elegant features of sticky defaults. First, because the statute's presumptions are heavy but not mandatory, it influences the meaning of no contest clauses and yet does not erect a bright-line restriction on testamentary freedom. Second, it achieves this result without requiring testators or attorneys to modify their behavior. Like any well-drafted sticky default, section 21305 helps testators reap the benefits of a well-calibrated clause even if they continue to employ the same formerly-overbroad no contest language.

In fact, section 21305 appears to have done even more to push the law in the right direction. The wills in our sample reveal that the statute may have made no contest clauses more visible to testators and attorneys. Indeed, after 2001, the following statistically significant changes occurred: (1) fewer testators included a no contest clause, (2) more wills featured a custom-made no contest provision, and (3) even controlling for other variables through a logit regression analysis,

16. Chin Will, supra note 1 , at 2 .

17. See id. at 1 .

18. See infra notes Part III.B. Of course, it is possible (albeit highly unlikely) that Chin wanted to preclude Gordon from taking even these non-controversial actions.

19. See Burch v. George, 866 P.2d 92, 102 (Cal. 1994); see also infra text accompanying notes 12128.

20. CAL. PROB. CODE $\S 21305$ (West 2002). Lawmakers eventually rephrased and renumbered the statute. See CAL. PROB. CODE $\S \S 21311(a)(2)-(3)$ (West 2018); see also infra text accompanying note 169.

21. See infra text accompanying notes $128-31$. 
the odds of finding a seemingly gratuitous no contest term declined. These findings support our claim that sticky defaults can serve as an antidote to intentthwarting boilerplate.

The Article proceeds as follows. Part II sets the stage by contrasting the issue of stock language in wills within the better-known topic of boilerplate in the commercial setting. Part III provides the background necessary to understand no contest clauses. Part IV details our research methodology and results. Part V concludes.

II

\section{BOILERPLATE: FROM CONTRACTS TO WILLS}

There is a rich literature on boilerplate in contracts. This Part briefly describes the debate over the efficacy of boilerplate in contracts and explains its relationship to our work on boilerplate in wills.

Scholarship on boilerplate in commercial transactions generally falls into one of two camps. One focuses on business-to-business exchanges. In this realm, "boilerplate"-which is defined as "standard clauses lifted from other agreements on file or in form books" 22 - has both payoffs and drawbacks. On the plus side, a widely-used term can confer both "learning benefits," such as clarity of meaning as a result of judicial interpretation, and "network benefits" of better professional services as lawyers become more familiar with the particular clause. ${ }^{23}$ On the flip side, boilerplate can also exhibit "spectacularly, almost ostentatiously, bad drafting." ${ }^{24}$ For example, Stephen J. Choi, Mitu Gulati, and Robert E. Scott examined pari passu provisions in sovereign bond contracts and discovered that they contained "black holes": language that has no "recoverable meaning." ${ }^{25}$ Choi, Gulati, and Scott traced this glitch to the knee-jerk repetition of a clause despite an absence of judicial rulings construing it. ${ }^{26}$ As they explained, "some standardized terms may get used by rote so consistently that they lose a shared meaning and become a ritualized legal incantation." 27

Commentators in the second camp examine boilerplate within "contracts of adhesion": pre-printed, non-negotiable terms that companies foist upon individuals. ${ }^{28}$ Discussions in this sphere are fiercely political. In one corner, conservatives and pro-business groups defend boilerplate as a practical necessity. They

22. E. Allan FARnSWORTH, CONTRACTS §7.1, at 426 (3d ed. 1999).

23. Marcel Kahan \& Michael Klausner, Standardization and Innovation in Corporate Contracting (or "The Economics of Boilerplate"), 83 VA. L. REV. 713, 722 (1997).

24. John F. Coyle \& W. Mark C. Weidemaier, Interpreting Contracts Without Context, 67 AM. U. L. REV. 1673, 1676 (2018).

25. Stephen J. Choi et. al., The Black Hole Problem in Commercial Boilerplate, 67 DuKE L.J. 1, 34 (2017).

26. See id. at 8.

27. Id. at 5 .

28. See, e.g., Edwin W. Patterson, The Delivery of a Life-Insurance Policy, 33 HARV. L. REV. 198, 222 (1919) (calling life insurance policies "contracts of "adhesion"” because "[t]he contract is drawn up by the insurer and the insured, who merely 'adheres' to it, has little choice as to its terms"). 
note that the mass-market economy could not function without mass-produced contracts, which save parties the time, energy, and cost of negotiating every deal. ${ }^{29}$ Moreover, they claim that harsh terms lower prices and raise wages. ${ }^{30} \mathrm{In}$ the other corner, liberals and public interest organizations argue that because contracts are supposed to arise from mutual assent, and yet nobody reads the fine print, adhesion "contract" is an oxymoron. ${ }^{31}$ In addition, they accuse firms of engaging in private law reform by eliminating background entitlements such as the rights to go to court, to invoke warranties, and to recover consequential damages. ${ }^{32}$ Finally, they propose an array of solutions, including disclosures, case-bycase policing under the unconscionability doctrine, and outright bans on specific provisions. ${ }^{33}$

In Boilerplate and Default Rules, we found that wills suffer from some of the flaws that make standardized contracts so polarizing. For starters, just like the black holes in sovereign debt agreements, several Sussex County documents featured sentences that had decayed into semantic anti-matter. A prime example was terms that governed "representation": the method for allocating assets among multiple generations. ${ }^{34}$ About twenty percent of estates tacked language of representation onto gifts to a single beneficiary, a context in which it is a nonsequitur. ${ }^{35}$

29. See, e.g., Jeremy McClane, Boilerplate and the Impact of Disclosure in Securities Dealmaking, 72 VAND. L. REV. 191, 213 (2019) ("Much of the robust literature on boilerplate espouses the idea that boilerplate enhances efficiency, reducing transaction costs to the contracting parties.").

30. See, e.g., Alan Schwartz \& Louis L. Wilde, Intervening in Markets on the Basis of Imperfect Information: A Legal and Economic Analysis, 127 U. PA. L. REV. 630, 648-49 (1979) (observing that consumers can force sellers to lower prices if they shop for favorable terms). This theory occasionally pops up in judicial opinions, as well. See, e.g., Carbajal v. H \& R Block Tax Servs., Inc., 372 F.3d 903, 906 (7th Cir. 2004) ("Forms reduce transactions costs and benefit consumers because, in competition, reductions in the cost of doing business show up as lower prices ...."). Similarly, some law and economics disciples argue that firms often relax form provisions to curry favor with valued customers and workers. See Lucian A. Bebchuk \& Richard A. Posner, One-Sided Contracts in Competitive Consumer Markets, 104 MICH. L. REV. 827, 827-28 (2006) ("A seller concerned about its reputation can be expected to treat consumers better than is required by the letter of the contract."); Jason Scott Johnston, The Return of Bargain: An Economic Theory of How Standard-Form Contracts Enable Cooperative Negotiation between Businesses and Consumers, 104 MiCH. L. REV. 857, 865 (2006) ("The common practice among firms is to give their employees the discretion to depart from these standard-form terms and to deliver more than the firm has actually promised if deemed in the firm's best interest to do so.").

31. See, e.g., Robin Bradley Kar \& Margaret Jane Radin, Pseudo-Contract and Shared Meaning Analysis, 132 HARV. L. REV. 1135, 1139-40 (2019) (arguing that "'contract'-which now allows businesses to create legal obligations unilaterally without obtaining any actual agreement over many boilerplate 'terms' - is no longer contract"); James Gibson, Boilerplate's False Dichotomy, 106 GEO. L.J. 249, 256 (2018) ("Consumers simply do not have the time or expertise to absorb all of the boilerplate they encounter and factor it into their purchasing decisions.").

32. See, e.g., MARgaret JANE RAdin, BoIlerplate: The Fine Print, VANishing Rights, AND THE RULE OF LAW 105 (2012) (referring to "boilerplate rights deletion schemes").

33. See id. at 189-96; Ian Ayres, Regulating Opt-Out: An Economic Theory of Altering Rules, 121 YALE L.J. 2032, 2068-83 (2012) (analyzing ways in which policymakers can design rules to "nudge" parties toward making wise choices).

34. Weisbord \& Horton, supra note 10, at 692.

35. Id. at 694 . 
Another illustration of meaningless boilerplate involves the intersection of the antilapse statute and survival conditions. Antilapse comes into play if a beneficiary dies before the testator. Very roughly, if the predeceased beneficiary is related to the testator, antilapse gives the property to the predeceased beneficiary's descendants. ${ }^{36}$ Alternatively, if the predeceased beneficiary is not tied by blood or adoption to the testator, the assets fall into the residue, which is a kind of safety net where residuary beneficiaries take all of the assets that the will has failed to give away. ${ }^{37}$ However, testators can override antilapse by using survivorship conditions, such as "to my daughter if she is then living." 38 Inexplicably, a handful of the New Jersey wills imposed survivorship mandates on gifts to nonrelatives. ${ }^{39}$ Because antilapse cannot apply to these people, these provisions were linguistic white noise.

In a faint echo of the critique of adhesion contracts, we also discovered that boilerplate in wills tends to oust majoritarian default rules. New Jersey follows the Uniform Probate Code (UPC), which calibrates its background principles to "effect[uate] the intent of a decedent." ${ }^{40}$ Paradoxically, many of the terms under our microscope opted out of this testator-friendly rubric. Consider the division of estate and inheritance taxes. The Garden State embraces the doctrine of equitable apportionment, which presumes that each beneficiary must pay a proportionate share of the tax bill. ${ }^{41}$ The logic here is simple: if A gets $75 \%$ of the testator's assets and $B$ receives $25 \%$, it is only fair to charge A with $75 \%$ of the tax liability. Nevertheless, 124 wills - roughly half - made the residuary beneficiaries responsible for the entire amount. ${ }^{42}$ Because the residuary beneficiaries tend to be a testator's beloved friends and family, these clauses are dubious. In fact, some veteran probate attorneys view them as "malpractice per se." 43 Therefore, wills, like contracts, contain form terms that only appear to bear the testator's stamp of approval.

36. See N.J. STAT. ANN. § 3B:3-35 (West 2019) ("If a devisee who is a grandparent, stepchild or a lineal descendant of a grandparent of the decedent is dead at the time of the execution of the governing instrument fails to survive the decedent ... any descendants of the deceased devisee ... take by representation in place of the deceased devisee.").

37. See Weisbord \& Horton, supra note 10, at 676-77 (noting that antilapse does not apply when the predeceased beneficiary is not related to the testator).

38. Id. at 691.

39. See id. ("[W]e unearthed four wills that imposed survivorship conditions on beneficiaries who did not qualify for antilapse protection.").

40. UNIF. PROB. CODE $\S 1-102$ (b)(2) (amended 2010).

41. N.J. STAT. ANN. § 3B:24-4 (West 2019); see also Weisbord \& Horton, supra note 10, at 682 (noting that equitable apportionment is the "runaway majority approach.").

42. Weisbord \& Horton, supra note 10, at 702.

43. Id. at 683 (quoting Daniel B. Evans, Tax Clauses to Die For, 20 ProB. \& Prop., July/Aug. 2006, at 38). 
Of course, testamentary boilerplate also differs from its contractual cousin. For one, wills do not involve the same risks of unfairness and drafter overreaching. ${ }^{44}$ Corporations weaponize consumer and employment contracts, business partners are also adversaries, and "[c]ontract law does not require parties to behave altruistically toward each other." ${ }^{45}$ Conversely, estate plans are collaborations between attorneys and clients. In fact, lawyers have ethical obligations to ensure that testators know how their property is going to be handled after they die. ${ }^{46}$ Thus, intent-perverting boilerplate in wills stems from sloppiness, not opportunism.

Similarly, boilerplate may persist in each type of document for unique reasons. Recall that Choi, Gulati, and Scott attributed black holes in sovereign debt agreements to the interpretive vacuum caused by the lack of any "legal challenges or other methods of validation [to] affirm the meaning of a routinely invoked term." ${ }^{\prime 7}$ Conversely, analogous provisions in wills are routinely litigated. For example, since at least the 1700 s, wills have included "just debts" clauses: short paragraphs at the beginning of the instrument that instruct the executor to "pay all of my just debts as soon as practicable." ${ }^{48}$ Indeed, ninety-six percent of the Sussex County instruments featured such a command. ${ }^{49}$ These clauses add nothing because executors already must satisfy an estate's creditors. ${ }^{50}$

In addition to being superfluous, a just debts term can sow confusion when the testator devises real property that is subject to a mortgage. Under the nonexoneration default, courts presume that the recipient of the land must discharge the loan. ${ }^{51}$ But because the executor uses the residue to settle the testator's outstanding obligations, a just debts clause arguably passes the buck to the residuary beneficiaries. ${ }^{52}$ Courts have spent decades trying to resolve this dilemma even though they acknowledge that just debts clauses are "legally meaningless." ${ }^{53}$ So why do testators cling to this language? As the Supreme Court of Georgia opined,

44. See Weisbord \& Horton, supra note 10, at 675 (noting that unlike in the drafting of some contracts, wills are drafted through a collaborative process involving much input and oversight by the testator).

45. Original Great Am. Chocolate Chip Cookie Co. v. River Valley Cookies, Ltd., 970 F.2d 273, 280 (7th Cir. 1992).

46. See, e.g., Daniel J. Hoffheimer et. al., Professionalism in Estate Planning, Trust, and Probate Law, 14 OHIO PROB. L.J. 84, 87 (2004) (noting that lawyers have a duty to "explain[] all of the legal planning alternatives and their potential risks and outcomes" to clients).

47. Choi et al., supra note 25 , at 8.

48. Weisbord \& Horton, supra note 10, at 679 (quoting Anderson v. Menefee, 174 S.W. 904, 905 (Tex. Civ. App. 1915)).

49. Id. at 698 .

50. Id. at 679 .

51. N.J. STAT. ANN. § 3B:25-1 (West 2019); see also Weisbord \& Horton, supra note 10, at 695-96 (noting that under this default "a beneficiary who inherits real property is responsible for any outstanding mortgage or security interest on the property").

52. See id. at 679-81 ("Mortgages are debts, and when a testator demands the satisfaction of her 'just debts' - but does not specify where the money should come from - she seems to instruct the executor to drain the residue.").

53. Id. at 679-80 (quoting In re Mayer's Estate, 137 A. 627, 629 (Pa. 1927)). 
it may be because it expresses their desire "to leave the world with [their] accounts paid and to be remembered as an upright and respectable person." ${ }^{54}$ Thus, some boilerplate in wills might survive simply because it inspires a visceral reaction.

Finally, we believe that the legal system should make the default rules that govern certain low-profile topics stickier. ${ }^{55}$ For example, lawmakers and courts could refuse to enforce provisions that shift taxes or mortgage debt to the residue unless the testator added her initials or specifically listed each asset to which this counter-intuitive regime applied. ${ }^{56}$ Forcing testators to take this additional measure would disable plain vanilla tax apportionment and just debts provisions and therefore diminish the risk of boilerplate overriding majoritarian default rules. Likewise, the extra labor required to give one's imprimatur to a default-reversing term could capture testators' attention, prompting them to learn more about the topic.

In summary, boilerplate can wreak havoc in both contracts and wills. Indeed, estate plans sometimes contain form terms that the testator probably did not read, or at least did not understand. In the remainder of the Article, we examine one especially troublesome manifestation of this phenomenon: the no contest clause.

III

\section{No CONTEST Clauses}

This Part offers a primer on no contest clauses. It begins by discussing why these provisions are controversial. It then contextualizes our research by zooming in on California's approach to the topic.

\section{A. "Terror in Probate" 57}

A no contest clause usually states that anyone who tries to invalidate a will cannot inherit under it. Testators have included these provisions for centuries. ${ }^{58}$ And for nearly as long, the law has struggled to regulate them. ${ }^{59}$

No contest clauses stand at the crossroads of powerful, conflicting policies. On the one hand, there are compelling reasons to enforce these provisions. For starters, doing so dovetails with the tradition of honoring donative autonomy.

54. Manders v. King, 667 S.E.2d 59, 61 (Ga. 2008).

55. See Weisbord \& Horton, supra note 10, at 703-10 (noting how sticky default rules "are a better choice for non-salient issues").

56. Id. at 707 .

57. We borrow the title of this Subpart from Selvin, supra note 5.

58. See Anonymous, 86 Eng. Rep. 910, 910 (1674) (featuring an instrument stating "[i]f A. molest B. by suit or otherwise, he shall lose what is devised to him, and it shall go to B").

59. See In re Brush's Estate, 154 Misc. 480, 480, 277 N.Y.S. 559, 560 (Sur. 1935), aff'd sub nom. In the Matter of Brush, 247 A.D. 760, 287 N.Y.S. 151 (App. Div. 1936) ("[T]here are few subjects of testamentary interpretation, the principles concerning which are in a more nebulous and unsatisfactory state."). 
Because testamentary freedom is the first principle of American wills and trusts law, a person may generally "dispose of $\mathrm{h}[\mathrm{er}]$ property as [s] he pleases." ${ }^{60}$ For example, courts generally uphold conditional bequests, such as those requiring a beneficiary to marry a member of a particular religion ${ }^{61}$ or not to use "liquors or tobacco, visit[] disreputable places, [or make] immoral associations." ${ }^{2}$ Arguably, a no contest clause is just another string attached to a gift. It gives unhappy beneficiaries the choice between standing down and inheriting or suing and possibly taking nothing. ${ }^{63}$

In addition, no contest clauses minimize social costs by discouraging litigation. Probate claims are notorious for being "strike suit[s]": little more than efforts to extort a quick settlement. ${ }^{64}$ Making matters worse, fraud, incapacity, and undue influence challenges can expose intimate details about the testator's life, drain the estate, and tear families apart. ${ }^{65}$ Thus, deterring these claims "contribute[s] to the fair reputation of the dead and to the peace and harmony of the living." ${ }^{66}$

But on the other hand, no contest clauses impede access to the judicial system. This can have pernicious effects. If beneficiaries with legitimate grievances "are forced to remain silent, ... the court will be prevented by the command of the testator from ascertaining the truth. ${ }^{{ }^{67}}$ In turn, this can embolden wrongdoers and undermine society's interest in detecting and punishing anti-social conduct. ${ }^{68}$

60. Lehman v. Lindenmeyer, 109 P. 956, 959 (Colo. 1909); see also Hodel v. Irving, 481 U.S. 704, 716 (1987) (" $[\mathrm{T}]$ he right to pass on property ... has been part of the Anglo-American legal system since feudal times.”); RESTATEMENT (THIRD) OF PROP.: WILLS AND OTHER DONATIVE TRANSFERS § 10.1 cmt. a (2003) ("The organizing principle of the American law of donative transfers is freedom of disposition.").

61. See, e.g., Shapira v. Union National Bank, 315 N.E.2d 825, 827-32 (Ohio 1974) (upholding a clause that required one of the testator's sons to marry a Jewish woman within seven years); Jeffrey G. Sherman, Posthumous Meddling: An Instrumentalist Theory of Testamentary Restraints on Conjugal and Religious Choices, 1999 U. ILL. L. REV. 1273, 1276-77 ("Courts traditionally have upheld these testamentary conditions calculated to restrain legatees' personal conduct, unless the conditions violate public policy.").

62. Onderdonk v. Onderdonk, 5 N.Y.S. 242, 242 (Gen. Term 1889), aff'd, 27 N.E. 839 (N.Y. 1891).

63. We say "possibly" for two reasons. First, a beneficiary who succeeds in overturning a will cannot be penalized by a no contest clause in that (now invalid) instrument. Second, as we mention below, a majority of jurisdictions recognize a "probable cause" exception to no contest provisions. Thus, a beneficiary might sue, lose, and still not be penalized.

64. John H. Langbein, Living Probate: The Conservatorship Model, 77 MicH. L. REV. 63, 66 (1978); cf. Barry v. Am. Sec. \& Trust Co., 135 F.2d 470, 473 (D.C. Cir. 1943) ("Studies which have been made show that only a very small percentage of will contests made on the grounds of defective execution, mental incapacity or undue influence are successful.").

65. See, e.g., Smithsonian Inst. v. Meech, 169 U.S. 398, 415 (1898).

66. Rudd v. Searles, 160 N.E. 882, 886 (Mass. 1928); see also Browder, supra note 5, at 1070 (observing that no contest clauses "discourage litigation which results in wasting testator's estates, in stirring up family animosities, and often in defaming testators' reputations when they are not alive to defend themselves").

67. S. Norwalk Tr. Co. v. St. John, 101 A. 961, 963 (Conn. 1917).

68. See Browder, supra note 5, at 1071 ("It would be easy, for example, for one who fraudulently obtains a share of the testator's estate or secures the same by undue influence to cover his tracks by seeing to it that a clause of forfeiture was added."). 
Ironically, one of the first ways that courts tried to balance these concerns was through a primitive sticky default rule. In the seventeenth century, English chancery courts voided no contest provisions unless the testator made a gift over by clarifying what happened to the forfeited property. ${ }^{69}$ The gift over doctrine served as a sincerity check. If the testator took this further step, courts "presume[d] that [s]he really meant what [s]he said."70 Conversely, if the testator offered no guidance on what happened to the defaulted share, judges would conclude that she meant the no contest provision to be merely "in terrorem": ${ }^{71}$ a nonbinding attempt to "frighten or to caution the beneficiary." 72 In this way, the gift over rule, like all sticky defaults, ignored the plain language of an instrument unless a party jumped through an additional hoop.

Modern American law governing no contest clauses is a cacophony of divergent rules. ${ }^{73}$ These approaches run the gamut from flatly invalidating to blindly enforcing no contest provisions. ${ }^{74}$ Many states, the UPC, and the Restatement of Property stake out a middle ground by refusing to disinherit any beneficiary who pursues a claim with "probable cause." 75 Likewise, several jurisdictions recognize

69. See, e.g., Pullen v. Ready, 26 Eng. Rep. 751, 752 (1743) (noting that a condition with "no devise over attending upon it" is void); Cooke v. Turner, 153 Eng. Rep. 1044, 1046 (Ex. 1846) (mentioning that this rule also applied to no contest clauses). Because chancery courts had jurisdiction over personal property, the "gift over" doctrine did not apply to devises of real estate. WILLIAM J. BOWE \& DOUGLAS H. PARKER, PAGE ON THE LAW OF WILLS § 44.29, at 470 (1962).

70. Browder, supra note 5, at 1093.

71. Id.

72. Id.; see also Cooke, 153 Eng. Rep. at 1046 ("A condition that the legatee shall not dispute the will is, in general, considered in terrorem merely ....").

73. Georgia continues to follow the "gift over" rule. See GA. CoDE ANN. § 53-4-68 (West 2019) (declaring that no contest provisions in wills are invalid and void unless there is "a direction in the will as to the disposition of the property if the condition . . . is violated"). But see RESTATEMENT (THIRD) OF PROP.: WILLS AND OTHER DONATIVE TRANSFERS $§ 8.5$ (2003) ("The absence of a gift over upon instituting proceedings has no effect."); Moskowitz v. Federman, 51 N.E.2d 48, 54 (Ohio 1943) (calling the "gift over" rule an "incongruous fiction").

74. Compare Fla. STAT. ANN. $\$ 732.517$ (West 2019) (voiding no contest clauses), with Ackerman v. Genevieve Ackerman Family Trust, 908 A.2d 1200, 1202 (D.C. 2006) (strictly enforcing a no contest clause), and Dainton v. Watson, 658 P.2d 79, 82 (Wyo. 1983) (same).

75. See UNIF. PROB. CODE $§ 2-517$ (amended 2010); RESTATEMENT (THIRD) OF PROP.: WiLLS AND OTHER DONATIVE TRANSFERS § 8.5; ARIZ. REV. STAT. ANN. § 14-2517 (West 2019); COLO. REV.STAT. ANN. § 15-12-905 (West 2019); MinN. STAT. AnN. § 524.2-517 (West 2019); N.J. STAT. AnN. § 3B:3-47 (West 2019); Matter of Estate of Primiani, No. 34200-0-III, 2017 WL 1655759 (Wash. App. May 2, 2017) ("[A] no contest clause is inoperable if the challenger brings his or her contest in good faith and with probable cause."). Some states recognize the probable cause exception only for specific allegations, such as forgery. See, e.g., OR. REV.STAT. ANN. § 112.272(2)(A)(a) (West 2019). "Probable cause" means "the existence, at the time of the initiation of the proceeding, of evidence which would lead a reasonable person, properly informed and advised, to conclude that there is a substantial likelihood that the contest or attack will be successful.” RESTATEMENT (SECOND) OF PROP.: DONATIVE TRANSFERS $§ 9.1 \mathrm{cmt}$. j (1983). 
idiosyncratic exceptions, such as for claims brought by "[a]n infant or [an] incompetent" ${ }^{76}$ or for those that seek to remove an executor ${ }^{77}$ interpret a will, ${ }^{78}$ or obtain "a ruling on [a] ... matter where a court has discretion." 79

Even with all this doctrinal instability, perhaps no state has struggled as mightily with no contest clauses as California. In the next subpart, we examine the Golden State's fraught relationship with these terms.

\section{B. No Contest Clauses in California}

For much of the twentieth century, California's stance on no contest clauses was impossible to pin down. This Subpart explains how a rash of inconsistent cases prompted lawmakers to experiment with a sticky default rule.

In 1909, the California Supreme Court confronted a no contest provision for the first time in Estate of Hite. ${ }^{80} \mathrm{John}$ Hite left $\$ 5,000$ to Etta Gross, the child of an old friend, and the rest of his property largely to his relatives. ${ }^{81}$ Hite's will also stated that anyone who contest[ed] it would "receive no part whatever of [the] estate." $" 82$ Hite then executed two codicils, one of which reduced Gross's inheritance to $\$ 2,000 .^{83}$ Gross challenged this document on the grounds of improper execution, undue influence, and incapacity ${ }^{84}$ After her petition was set for hearing, the matter settled. ${ }^{85} \mathrm{~A}$ residuary beneficiary then argued that Gross had violated the no contest clause. ${ }^{86}$ The state high court agreed, reasoning that a contest occurs when a party attempts to "thwart[] . . the testator's expressed wishes," 87 and that Gross had crossed this line by pursuing her objection on the eve of trial. ${ }^{88}$

76. N.Y. EST. POWERS \& TRUSTS L. § 3-3.5(b)(2) (McKinney 2019).

77. See Estate of Wojtalewicz v. Woitel, 418 N.E.2d 418, 420-21 (Ill. App. Ct. 1981) (finding that enforcement of clause to prohibit the challenging of an executor unenforceable and against public policy).

78. See, e.g., N.H. REV. STAT. ANN. § 551:22.III(d) (West 2019) (noting that challenging the "construction or interpretation of the will" does not violate no contest provisions).

79. IND. CODE ANN. § 29-1-6-2(b)(6) (West 2019); cf. In re Andrus' Will, 281 N.Y.S. 831, 852, 861 (Sur. 1935) (refusing to enforce no contest clause in trust that was "broad enough to absolve the trustees during the entire terms of the trusts from all responsibility for their actions, regardless of the legality of their administration of the trusts").

80. 101 P. 443 (Cal. 1909).

81. Id. at $443-44$.

82. Id. at 444 .

83. Id.

84. See id.

85. See id.

86. See id.

87. Id. at 446. The court declined to adopt the "gift over" doctrine, reasoning that it laid upon "an insecure foundation." Id. at 447.

88. See id. at 444-48. The justices left room open for a litigant who abandoned her claim earlier to avoid being disinherited by remarking that "the mere filing of a paper contest, which has been abandoned without action, and has not been employed to thwart the testator's expressed wishes, need be judicially declared a contest." Id. at 446. However, courts have been reluctant to dismiss actions as mere "paper contest[s]." See In re Fuller's Estate, 300 P.3d 342, 348 (Ct. App. 1956) (finding that the beneficiary violated no contest clause by filing opposition to probate of will that was dismissed three months later). 
However, the state high court soon muddied the waters in Estate of Bergland. ${ }^{89}$ In 1910, Andrew Bergland executed a will that gave his property to his children and disinherited anyone who "attempt[ed] to defeat [its] provisions." 90 After Bergland died, his daughter, Kate Misner, sought to probate two handwritten documents. ${ }^{91}$ One was dated August 29, 1915, and gave Bergland's bank accounts to Misner. ${ }^{92}$ The other was dated December 25, 1915, and also left Misner more than the will did. ${ }^{93}$ Ultimately, the court admitted the August 29 codicil to probate, but Misner abandoned her effort to validate the December 25 instrument, which turned out to be a forgery. ${ }^{94}$ Bergland's sons then claimed that Misner had violated the no contest clause in the 1910 will. ${ }^{95}$

The California Supreme Court rejected this argument for two reasons. First, the justices opined that the bogus December 25 codicil did not mention the 1910 will and thus was distinct from the underlying no contest clause. ${ }^{96}$ Second, the court declared that " $\mathrm{t}$ ] he forfeiture provision has no application to an attempt made in good faith to probate what purports to be a later will." 97 Because there was no evidence that Misner had acted with malice, the justices held that she did not need to surrender her inheritance. ${ }^{98}$

The conflict between Hite and Bergland was stark. Both beneficiaries had done similar things - Gross had objected to a valid codicil and Misner had tried to probate an invalid codicil - but only Gross had been penalized. Considering the language of each no contest clause made things even hazier. If anything, the provision in Hite was narrower than the one in Bergland. Indeed, the former merely prohibited contests, ${ }^{99}$ but the latter governed "attempt[s] to defeat the provisions of this will." 100 The court did not explain how Misner's support of the

89. 182 P. 277 (Cal. 1919).

90. Id. at 278 .

91. Id.

92. Id.

93. See id. (noting that this instrument would have disposed of the decedent's property in a much different way than in the original will, and that this would be advantageous to Misner).

94. See id. The opinion is bizarrely coy about this issue, stating only that the petition to probate the December 25, 1915 document "was withdrawn, and ... a certain person was convicted of the crime of forging it." $I d$.

95. Id.

96. See id. at 278 ("[T] he forfeiture clause contained in the will ... has no application to the [codicil] of 1915 or to the legacy given by it."). In addition, the court observed that taking the no contest clause at face value could spawn absurd results. For example, because Bergland's sons had objected to Misner's petition to probate the authentic August 29 codicil, they too had attempted to thwart Bergland's intent and should be stripped of their legacies. See id. at 279.

97. Id. at 280 .

98. See id. ("[A]n attempt in good faith to probate a later purported will, spurious in fact, but believed to be genuine by the party seeking its probate, does not fall within the forfeiture clause under consideration here.").

99. In re Estate of Hite 101 P. 443, 443 (Cal. 1909).

100. In re Estate of Bergland 182 P. 277, 278 (Cal. 1919). 
phony codicil - a document which would have disfigured Bergland's original dispositive scheme - was not an "attempt to defeat [the will's] provisions." ${ }^{101}$ Finally, the two opinions viewed no contest clauses differently. Hite praised them for preventing litigation, ${ }^{102}$ but Bergland warned that because they can generate harsh results, they must "be strictly construed and not extended beyond what was plainly the testator's intent." 103

As the decades passed, the outcome of no contest litigation in California continued to be "difficult to predict." ${ }^{104}$ Two rough lines of authority emerged. One ignored Bergland or limited it to its facts. ${ }^{105}$ For example, in Estate of Howard, an appellate panel disinherited the testator's husband for asserting that part of the estate was his community property. ${ }^{106}$ The testator had used an estate planning technique known as the spousal election, which entailed leaving her husband a generous gift, inserting a no contest clause that covered challenges to the will's provisions, declaring that certain assets were her separate property, and devising these assets to other people. ${ }^{107}$ As the court recognized, this maneuver gave the husband a choice: he could "either rely upon his claim of ownership and waive his rights under the will, or accept the provisions of the will and waive his rights of ownership." 108 Because he went down the former path, he had violated the no contest clause's admonition not to attack the will's provisions. ${ }^{109}$

101. See id. at 278-80 ("The attempt to probate a later will cannot be said to be an objection to the distribution made by the first will.").

102. See Hite, 101 P. at 444 ("Public policy ... deplores litigation.").

103. Bergland, $182 \mathrm{P}$. at 279.

104. Selvin, supra note 5, at 356.

105. See, e.g., In re Estate of Markham, 115 P.2d 866, 870 (Cal. 1941) (opining that Bergland's good faith exception does not govern "a direct attempt to challenge the validity of the will or defeat its provisions"); In re Kitchen, 220 P. 301, 302 (Cal. 1923) (holding that beneficiary's allegation that the testator had breached an oral contract to compensate her for caregiving services in his will violated a provision that barred "su[ing] and disturb[ing] ... my executor").

106. 155 P.2d 841, 841 n.1, 842 (Cal. 1945).

107. See id. at 842. The spousal election is sometimes referred to by the anachronistic (and in Howard, inaccurate) name of "widow's election." Estate of Webb, 142 Cal. Rptr. 642, 644 (Ct. App. 1977).

108. Howard, 155 P.2d at 842 .

109. See id. (noting that the husband had "claim[ed] to be the owner" of items that "clauses of decedent's will ... referred to ... as her 'separate property'"); accord Estate of Kazian, 130 Cal. Rptr. 908, 910 (Ct. App. 1976) (finding the same result where the testator "specifically declared that all property in her name was her sole and separate property" and the no contest clause applied to attempts to "contest [the will], or any of its parts or provisions"). But see Estate of Richter, 16 Cal. Rptr. 2d 108, 113 (Ct. App. 1993) (holding that surviving spouse's assertion of community property rights was not a contest when the testator neither "purport[ed] to dispose of any particular assets" nor "state[d] unequivocally [that items in the estate] were his separate property"); Estate of Black, 206 Cal. Rptr. 663, 665, 669 (Ct. App. 1984) (finding the same result where beneficiary sought to assert implied domestic partnership rights and the will did not "expressly refer[] to designated property as separate property"); $c f$. Estate of Dow, 308 P.2d 475, 480 (Cal. Ct. App. 1957) (finding that "the offering of proof to show that all, any or no part of the estate is community property, will not violate an in terrorem provision of a will"). 
Conversely, other judges held that no contest provisions only governed allegations that an instrument was void under fraud, incapacity, or undue influence. ${ }^{110}$ This forgiving rubric spared beneficiaries who argued that property did not belong to the estate because it was held in joint tenancy, ${ }^{111}$ contended that a testator had violated a statute that capped the amount one could bequeath to charity, ${ }^{112}$ testified on behalf of the contestants at trial, ${ }^{113}$ subsidized litigation against the estate ${ }^{114}$ and filed petitions to construe a will, ${ }^{115}$ terminate a trust, ${ }^{116}$ and remove an executor. ${ }^{117}$ As commentators noted, these divergent outcomes revealed that "California courts had yet to develop a ... coherent approach for interpreting no contest clauses." 118

This doctrinal turmoil came to a head near the dawn of the new millennium. In 1990, the California Law Revision Commission published a report voicing concern that "a beneficiary cannot predict with any consistency when an activity will be held to fall within the proscription of a particular no contest clause." 119 The legislature responded by passing Probate Code section 21304, which declared that "a no contest clause shall be strictly construed." ${ }^{120}$ By borrowing the "strictly construed" language from Bergland, lawmakers seemed to repudiate cases like Hite and Howard.

110. See, e.g., In re Estate of Miller, 41 Cal. Rptr. 410, 418 (Ct. App. 1964) ("[L]awyers and judges would normally read the word 'contest' as it is employed in the probate code."); cf. Selvin, supra note 5, at 356 (explaining that the probate code's definition of "contest" only includes "proceeding[s] designed to invalidate the will on the grounds of faulty execution, incompetency of the testator, or fraud or undue influence"). But see Estate of Friedman, 161 Cal. Rptr. 311, 315 (Ct. App. 1979) (reasoning in a case involving a broad no contest clause that "[ $t]$ he word 'contest' . . means any legal proceeding designed to result in the thwarting of the testator's wishes").

111. See Estate of Schreck, 121 Cal. Rptr. 218, 221 (Ct. App. 1975) (noting that no contest clause "appl[ied] only to those persons who seek to invalidate the will ... to acquire the testator's property by instestate succession").

112. See Estate of Basore, 96 Cal. Rptr. 874, 878 (Ct. App. 1971) (stating that the petitioner "did not actually oppose or contest" the will by alleging that he was "entitled to a ... portion of the residue ... which exceeds the amount distributable to charity").

113. See Lobb v. Brown, 281 P. 1010, 1014-15 (Cal. 1929) ("[A] legatee who testified as a witness without a subpoena at the request of the contestant ... did not thereby contest the will ....”).

114. See id. at 1016 (finding that "furnishing money to meet the expense of [another person's] contest" does not itself constitute a contest).

115. See Estate of Kruse, 86 Cal. Rptr. 491, 493 (Ct. App. 1970) ("[S]eeking an interpretation of a will does not in and of itself constitute an attempt to thwart the will of a testator.").

116. See Miller, 41 Cal. Rptr. at 417-19 (Ct. App. 1964) (explaining that seeking termination of a trust was not a contest to the will itself).

117. See Estate of Lewy, 113 Cal. Rptr. 674, 676 (Ct. App. 1974) (affirming probate court holding that attempted removal of testatrix did not constitute a contest).

118. Sharon J. Ormond, Comment, No Contest Clauses in California Wills and Trusts: How Lucky Do You Feel Playing the Wheel of Fortune?, 18 WhitTIER L. REV. 613, 617-18 (1997).

119. Recommendation Relating to No Contest Clauses, 20 CAL. L. REVISION COMM'N REPORTS 7, 12 (1990).

120. Jacobs-Zorne v. Superior Court, 54 Cal. Rptr. 2d 385, 390 (Ct. App. 1996) (quoting former CAL. PROB. CODE $§ 21304$ (repealed 2010)) (internal quotation marks omitted). The legislature also enacted Probate Code Section 21320, which created a safe harbor for beneficiaries to seek declaratory relief that a proposed petition did not violate a no contest clause. See Genger v. Delsol, 66 Cal. Rptr. 2d 527, 533 \& n.3 (Ct. App. 1997). 
Nevertheless, in 1994, the California Supreme Court seemed to ignore this directive in Burch v. George. ${ }^{121}$ Frank Burch executed an inter vivos trust to provide for his fifth wife Marlene and his other relatives. ${ }^{122}$ Like the testator in Howard, Frank used a spousal election. He transferred several assets to the trust that may have partially been Marlene's community property, including stock in his car dealership, benefits from that company's pension plan, and life insurance policies that the plan had purchased. ${ }^{123}$ Frank's trust declared that it consisted of his separate property and forbade any beneficiary from "seek[ing] . . to void, nullify or set aside this Trust or any of its provisions." ${ }^{124}$ After Frank died, Marlene sought declaratory relief that she could file two lawsuits without being disinherited: one for conversion against the trustees and another under the Employee Retirement and Income Security Act against the administrators of the pension plan. ${ }^{125}$ The court held that these petitions would unravel the spousal election, which was the cornerstone of Frank's "integrated estate plan." 126 Thus, because the lawsuits "were 'designed to thwart [Frank's] basic intent," they would violate the no contest clause. ${ }^{127}$

Shortly after Burch, legislators pushed back. Complaining that courts had read "generic 'no contest' clauses" too broadly and thus "introduced an unnecessary level of uncertainty and ultimately litigation into this area," they adopted Probate Code section 21305. ${ }^{128}$ This sticky default rule presumes that no contest clauses do not apply in certain situations unless the testator expressly dictates otherwise:

[T]he following actions do not constitute a contest unless expressly identified in the no contest clause as a violation of the clause:

(1) The filing of a creditor's claim or prosecution of an action based upon it.

(2) An action or proceeding to determine the character, title, or ownership of property.

(3) A challenge to the validity of an instrument, contract, agreement, beneficiary designation, or other document, other than the instrument containing the no contest clause. ${ }^{129}$

121. 866 P.2d 92 (Cal. 1994).

122. Id. at 94 .

123. Id. at 95 .

124. Id. at $97-98$.

125. Id.

126. Id. at 95,98 .

127. Id. Even after Burch, courts splintered over similar fact patterns. Compare Jacobs-Zorne, 54 Cal. Rptr. 2d at 393 (holding that beneficiary's allegation that bank accounts were held in joint tenancy did not violate a no contest clause because it did not "challeng[e] the validity of the will itself on grounds such as competence or undue influence or $\mathrm{s}[\mathrm{eek}]$ to have provisions of that will nullified or set aside"), with Estate of Pittman, 73 Cal. Rptr. 2d 622, 630 (Ct. App. 1998) (determining that beneficiaries violated no contest clause by asserting community property rights when the trust "characterized each piece of property as community property [or] separate property" because they "sought to disrupt this meticulously drawn distribution scheme").

128. CAl. Assembly COMM. ON Judiciary, Bill ANAlysis OF A.B. 1491 (Jan. 11. 2000).

129. CAL. Prob. CodE $\S 21305$ (West 2002). 
Section 21305 revolutionized California's approach to no contest provisions. Consider how the statute would have changed several seminal cases. For example, recall that Hite held that a challenge to the validity of a codicil violated a provision in the underlying will that disinherited beneficiaries for filing a contest. ${ }^{130}$ Yet if the testator had executed his will after January 1, 2001, the result would have been different. In the language of section 21305, the beneficiary targeted "an instrument" - the codicil - "other than the instrument containing the no contest clause" - the will - and the testator did not "expressly identif[y]" such a petition "in the no contest clause as a violation of the clause." Likewise, under the new law, the beneficiaries in Howard and Burch could have freely pursued their community property rights. ${ }^{131}$ After all, they filed "proceeding[s] to determine the character, title, or ownership of property," and the no contest provisions were silent about those claims. Thus, section 21305 forced any testator who truly wanted a no contest provision to stretch to the horizon to say so explicitly.

\section{IV}

\section{EMPIRICAL RESEARCH}

This Part capitalizes on an originally-collected dataset to examine boilerplate no contest clauses and the efficacy of sticky default rules. It begins by briefly describing our research methodology. It then presents and analyzes our results.

\section{A. Data Description}

One of us has written several articles based on probate administrations from Alameda County, California. Some of these papers feature a fine-grained dataset of fifty variables stemming from 668 estates that both (1) came on calendar between January 1, 2008 and March 1, 2009 and (2) stemmed from deaths in 2007 (the "original" sample) ${ }^{132}$ Others involve at least ten data points from (1) every case in the original sample and (2) all matters that the court heard between March 1, 2009 and December 31, 2010 (a "combined" sample of 2,453 observations). ${ }^{133}$

For this Article, we expanded both the original sample and a sliver of the combined sample. First, we enlarged the scope of the detail-rich original sample to include cases that appeared on the docket in March and April 2009. Second, we read and coded each will in this dataset, with an eye toward (1) determining what kind, if any, of no contest clause was included in the will, (2) whether the testator was married when the will was executed, (3) whether a will was self-

130. See supra text accompanying notes $80-88$.

131. See supra text accompanying notes 106-09, 121-27.

132. See, e.g., David Horton, In Partial Defense of Probate: Evidence from Alameda County, California, 103 GEO. L.J. 605, 624-27 (2015).

133. See, e.g., David Horton, Partial Harmless Error for Wills: Evidence from California, 103 IowA L. REV. 2027, 2045-48 (2018). These previous articles mention a few caveats that we will not repeat here, including the fact that California's status as a community property state means that we cannot help but over-sample unmarried decedents. See id. at 2048. 
made, (4) whether a just debts clause was included, ${ }^{134}$ and (5) whether it expressly disinherited anyone.

B. Results

\section{Overview}

No contest clauses are common in the Alameda County files. Our dataset consists of 442 relevant wills, ${ }^{135}$ and no contest provisions appear in 306 of them $(69.2 \%) .{ }^{136}$

These terms come in five basic varieties. First, some are "narrow." A narrow clause disinherits anyone who contests the will. For example, a testator named Frances Johnson declared that "if any person, whether a beneficiary under this Will or not mentioned herein shall contest this Will, I give to such person so contesting the sum of One Dollar ...." ${ }^{137}$ Narrow provisions are relatively rare: indeed, only eighteen $(4.1 \%)$ of the wills in our sample contained a no contest clause that fit this description.

Second, other provisions are "broad." A typical broad clause reads: "If any beneficiary under this Will in any manner, directly or indirectly, contests or attacks this Will or any of its provisions, any share or interest in my estate given to that contesting beneficiary under this Will is revoked ...."138

134. Just debts clauses, as noted above, are a widely reviled type of boilerplate which may indicate that less effort went into drafting or reviewing the instrument. See, e.g., Weisbord \& Horton, supra note 10 , at $679-82$.

135. There are 457 wills in our dataset. Because we are focusing on the impact of California law, we eliminated two instruments that were executed in other states. We also cut thirteen other wills that litigants challenged as invalid in a case that either went to trial or settled. We did so in an effort to balance two countervailing factors. On the one hand, if a will is contested, it is not clear that it truly represents the testator's intent. But on the other hand, excluding all challenged wills would risk underreporting the number of no contest provisions, because testators who anticipate trouble may be especially likely to include such a clause. We therefore decided to use the fact that a contest survived until the trial or settlement stage as a sign a will might not be legitimate and thus should be cut from our sample. Finally, one will lacks a date, and two wills are missing the page that contains most of the no contest provision. As the reader can see below, we include these three documents for some purposes, but not others.

136. In sharp contrast, only 20 of the 244 (8.2\%) wills in our New Jersey study included no contest clauses. This gulf is puzzling. In fact, in one way, it is the opposite of what one might expect. Unlike California, where the law has never been settled, New Jersey has long refused to enforce no contest clauses against petitions filed with "probable cause." Haynes v. First Nat. State Bank of New Jersey, 432 A.2d 890, 902 (N.J. 1981). We would assume that testators would be more likely to use a term if they could foresee how a judge would interpret it. Nevertheless, Alameda County testators routinely inserted no contest clauses and their counterparts in Sussex County did not. For another point of comparison, see Allison Dunham, The Method, Process and Frequency of Wealth Transmission at Death, 30 U. CHI. L. REV. 241, 284 (1963) (examining two groups of wills from Chicago in the 1950s and finding zero no contest clauses in one and three such provisions in the other).

137. Last Will and Testament of Frances H. Johnson at 1-2, In re Estate of Johnson, No. HP07345646 (Cal. Super. Ct. Oct. 19, 2007).

138. Last Will and Testament of Laszlo B. Gossler at 8, In re Estate of Gossler, No. RP08366657 (Cal. Super. Ct. Jan. 18, 2008). 
Unlike narrow clauses, broad clauses apply both to garden-variety contests and to other attempts to undermine the will's provisions. Broad clauses dominate the Alameda County files, appearing in $223(50.8 \%)$ wills.

Third, a handful of clauses are "very broad." These provisions penalize beneficiaries for conduct beyond merely filing a lawsuit. Consider Lillie Brooks's will, which is a veritable minefield for its beneficiaries:

If any devisee, legatee or beneficiary under this Will, or any other person claiming under or through any devisee, legatee or beneficiary ... shall in any manner whatsoever, directly or indirectly, contest this Will or attack, oppose or in any manner seek to impair or invalidate any provision thereof, or shall in any manner whatsoever conspire or cooperate with any person or persons attempting to do any of the acts or things aforesaid, or shall acquiesce in or fail to oppose such proceedings, then ... I hereby bequeath to such person or persons the sum of ONE DOLLAR .... 139

This language is more potent than a broad clause because it activates if a beneficiary simply sits on the sidelines and fails to resist another party's lawsuit. Very broad provisions surface in twenty-six $(5.9 \%)$ wills.

Fourth, some testators use "quasi-sophisticated" clauses. The hallmark of such a provision is its granularity: it expressly mentions the impact of either filing a particular claim or challenging an instrument other than the will. For instance, quasi-sophisticated clauses might make "the seeking of declaratory relief... equivalent to contesting the will" ${ }^{140}$ or govern attempts to invalidate the testator's pension, revocable inter vivos trust, or life insurance beneficiary designations. Twenty-seven $(6.2 \%)$ clauses offered this much detail.

Fifth, no contest provisions can be full-on "sophisticated." A sophisticated clause either spells out the consequences of bringing more than one kind of lawsuit or addresses multiple non-probate devices. In fact, most sophisticated clauses - like the one reproduced below - are so verbose that they meet both criteria:

If any person, directly or indirectly, contests the validity of this will in whole or in part, or opposes, objects to, or seeks to invalidate any of its provisions, or the validity of any contract, agreement (including any trust agreement), declaration of trust, beneficiary designation, or other document executed by me (or for my benefit) that is part of my integrated estate plan ... any gift or other interest given to that person under this will shall be revoked .... I specifically exempt petitions under California Probate Code sections 9860,17200 or 17200.1 from the effect of this clause. ${ }^{141}$

Ten $(2.3 \%)$ sophisticated provisions popped up in our data, which is reproduced in full in the chart below.

139. Last Will and Testament of Lillie M. Brooks at 3, In re Estate of Brooks, No. RP08399297 (Cal. Super. Ct. Jul. 21, 2008).

140. Will of Ethel Leonard at 3-4, In re Estate of Leonard, No. RP08365604 (Cal. Super. Ct. Feb. 1, 2008).

141. Last Will of Carlos Q. Luciano at 5, In re Estate of Luciano, No. RP08364463 (Cal. Super. Ct. Jan. 7, 2008). 


\begin{tabular}{|c|c|c|}
\hline \multicolumn{3}{|c|}{ Table 1: No Contest Clauses in All Wills } \\
\hline & $\mathrm{N}$ & Percent \\
\hline Broad & 223 & $50.8 \%$ \\
\hline None & 135 & $30.7 \%$ \\
\hline Quasi-Sophisticated & 27 & $6.2 \%$ \\
\hline Very Broad & 26 & $5.9 \%$ \\
\hline Narrow & 18 & $4.1 \%$ \\
\hline Sophisticated & 10 & $2.3 \%$ \\
\hline Total & 439 & $100 \%$ \\
\hline \multicolumn{3}{|c|}{$\begin{array}{l}\text { Notes: } \\
\text { This Table excludes two wills that are missing the } \\
\text { page that contains most of the no contest clause. }\end{array}$} \\
\hline
\end{tabular}

\section{No Contest Clauses as Intent-Defeating Boilerplate}

This Subpart argues that some of the no contest clauses in the Alameda County wills are boilerplate that distort the probable wishes of the testator. First, we show that drafters frequently copy these terms from other sources. Second, we contend that the risks of these provisions often outweigh the benefits.

At the outset, there are reasons to suspect that many no contest clauses are boilerplate. For starters, judges, scholars, and practitioners refer to them as such. ${ }^{142}$ Moreover, form books have featured readymade no contest provisions for decades, ${ }^{143}$ and "some attorneys believe it is malpractice not to include such a

142. See, e.g., McCaslin v. England, No. G046063, 2013 WL 1277887, at*3 (Cal. Ct. App. Mar. 29, 2013) (quoting a trial judge as remarking: "[T]his is a garden-variety boilerplate no-contest clause. It's not anything that you don't usually see"); Kara Blanco \& Rebecca E. Whitacre, The Carrot and Stick Approach: In Terrorem Clauses in Texas Jurisprudence, 43 TEX. TECH. L. REV. 1127, 1176 (2011) ("One could argue that a court should give greater deference to a uniquely tailored no-contest clause drafted with the testator's specific intentions in mind, rather than boilerplate no-contest language included in every testamentary instrument that the drafter of the instrument prepares.").

143. See Jack Leavitt, Scope and Effectiveness of No-Contest Clauses in Last Wills and Testaments, 15 HASTINGS L.J. 45, 45-46 \& nn.2-3 (1963) (quoting sample clauses published by Bank of America and Wells Fargo). 
clause." ${ }^{144}$ In some cases, lawyers have admitted inserting no contest language on their "own initiative" without "receiv[ing] explicit instructions" from a client. ${ }^{145}$

Given this backdrop, it is not surprising that the vast majority of the no contest clauses in our sample appear to be recycled. For example, broad clauses, which account for nearly three-quarters of the no contest provisions in our data, tend to be carbon copies of each other. They invariably consist of a single sentence that deletes the share of anyone who in any manner, directly or indirectly, contests or attacks the will or any of its provisions. ${ }^{146}$ This precise phraseology has appeared in California drafting manuals for more than half a century; ${ }^{147}$ in fact, commentators refer to it as the "generic 'no contest' clause." 148 There can be little question that this language is borrowed from templates or prior instruments.

However, this does not prove that no contest clauses are problematic. Even if drafters mindlessly regurgitate a provision, testators might notice it when they read their wills. In fact, no contest clauses are more conspicuous than the arcane terms we studied in Boilerplate and Default Rules. That article plumbed the depths of estate planning by surveying language that allocated responsibility for paying debts and taxes ${ }^{149}$-topics that testators might gloss over. Conversely, no contest clauses, which govern the operatic mix of litigation and disinheritance, likely stand out. Thus, whether no contest provisions are bespoke or borrowed, testators are probably aware of them.

Moreover, not all boilerplate is inconsistent with a testator's informed wishes. Arguably, no contest clauses are majoritarian. After all, nobody wants their estate to get bogged down in the judicial system. Perhaps the law is backwards, and suing should disqualify a beneficiary from receiving any of a decedent's bounty unless the will includes a contest authorization clause that states otherwise.

We uncovered support for this proposition in a surprising place: holographic wills. ${ }^{150}$ One would not expect to find any legalese in these self-made instruments. But six of the thirty-seven $(16.2 \%)$ holographs in our data boasted a no contest clause. Herbert Rodgers's will, pictured in Figure 1 below, is illustrative. It names an executor, lists assets, distributes them, and declares in the underlined portion: "If anyone file[s] claims to my estate, give them One Dollar." ${ }^{151}$ Likewise, other

144. Bashaw, supra note 8, at 351.

145. Genger v. Delsol, 66 Cal. Rptr. 2d 527, 530 (Ct. App. 1997).

146. See supra note 137 and accompanying text.

147. Ormond, supra note 118, at 663 n.12 (citing CALIFORNIA WILL FORMS MANUAL $§ 2.16$ (CEB 1966); Edith C. SCHAFFER, 1 CAL. TRANS. FoRMS-Estate PlANNING § 6:116 (2016)).

148. Vartuhi Torounian, Chapter 17: An Attempt to Improve the Existing Probate Law, 32 MCGEORGE L. REV. 681, 691 n.4 (2001).

149. See Weisbord \& Horton, supra note 10, at 668.

150. Both California and New Jersey validate wills that are largely in the testator's handwriting and signed by her (even if they are not signed by witnesses). See CAL. PROB. CODE $§$ 6111(a) (West 2019); N.J. STAT. ANN. \& 3B:3-2(b) (West 2019). However, for some reason, the sample of wills that we obtained from the Sussex County Surrogate to write Boilerplate and Default Rules did not include any holographs. Thus, we were not able to compare New Jersey self-made wills to their California equivalents.

151. Will of Herbert Rodgers at 1, In re Estate of Rodgers, No. RP07351944 (Cal. Super. Ct. Oct. 18, 2007). 
do-it-yourselfers expressed the same sentiment even if they did not translate it into a legal imperative. For example, Hannah Wit wrote a will in her diary and tossed in a dash of spice: "Anyone who doesn't believe that I am of 'sound mind' right now, writing this, is wrong. Anyone who contests this on the basis of some legal mumbo jumbo, I will have you know, I am rolling over in my grave now." 152

The existence of no contest terminology in these direct dispatches from the testator - the antithesis of boilerplate - highlights the intuitive desire to discourage litigation.

Figure 1: Herbert Rodgers's Holographic Will

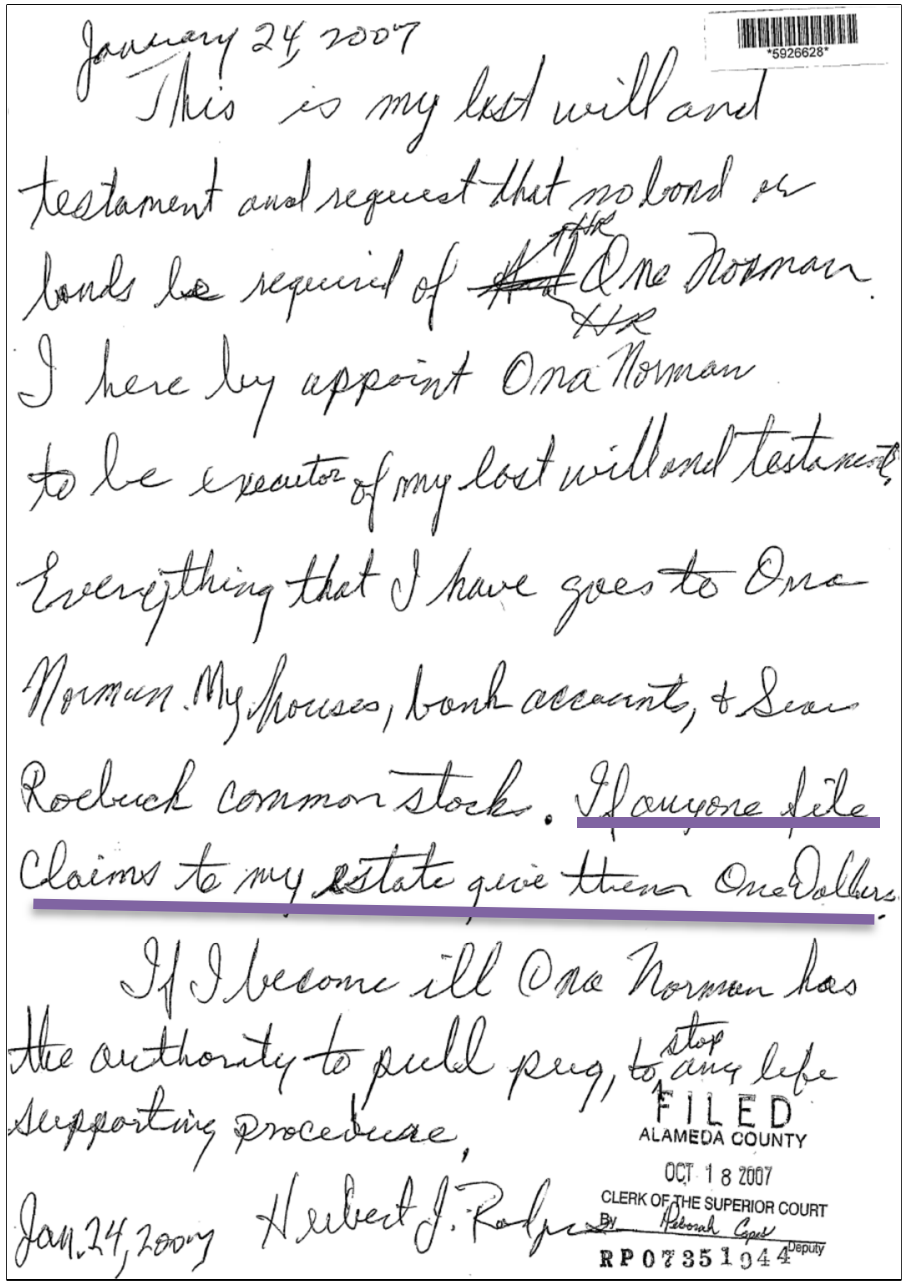

Then again, testators might embrace no contest language for emotional-rather than logical-reasons. Recall that judges have hypothesized that just debts

152. Petition for Probate of Will at 7-8, In re Estate of Wit, No. RP07362504 (Cal. Super. Ct. Jan. 3 2008). 
provisions remain common because they telegraph that the testator is an upstanding and responsible citizen. ${ }^{153}$ In the same vein, no contest clauses may be popular because they send a message. ${ }^{154}$ Perhaps testators like the way a no contest clause reinforces their commitment to their dispositive choices, like adding an exclamation point at the end of a sentence. In turn, this would raise questions about whether testators fully grasp what they are doing when they insert or approve such a provision.

Indeed, on closer inspection, some no contest clauses deviate from a testator's likely intent. Of course, because we did not interview the decedents who populate the Alameda County files, we can only guess about what they wanted to accomplish. ${ }^{155}$ Yet there are some telltale signs that the testators and their attorneys misunderstood the no contest mechanism. For example, of the fifty-five wills expressly disinherit an individual, and forty (73\%) of them contain a no contest clause. Occasionally, the language excluding the person appears in the same paragraph as the no contest provision. Consider Jesse Naputi's will, which leaves his daughter nothing:

Fifth. I have intentionally omitted to provide for Jennifer Ortega, who shall be deemed to have predeceased me with no issue. If any person ... for any reason or in any matter, directly or indirectly, contests the validity of this Will in whole or in part, on any ground, or opposes or objects to any of the provisions of the Will ... the contesting person shall not take anything from my estate. ${ }^{156}$

The proximity of these two terms implies that the testator meant to discourage the snubbed relative from suing. ${ }^{157}$ But the no contest clause fails to achieve this goal. To work, such a provision needs not only a stick, but also a carrot. Indeed, it must give the potential troublemaker enough to make her think twice before lawyering up. In contrast, a non-beneficiary like Naputi's daughter literally has nothing to lose. These unartful wills suggest that testators and their counsel do not always have a solid grasp of how no contest provisions operate.

Likewise, no contest clauses were common even in cases where beneficiaries were extremely unlikely to sue. Putting aside seventy-two pour over wills which give property to a trust and thus do not reveal the estate's true beneficiaries, 192 testators distributed property in a fashion that closely approximated California's

153. See supra text accompanying notes 52-53.

154. See generally David Horton, Testation and Speech, 101 GEO. L.J. 61 (2012) (arguing that testation is an important form of self-expression).

155. Cf. John F. Coyle, The Canons of Construction for Choice-of-Law Clauses, 92 WASH. L. REV. 631, 693-96 (2017) (interviewing drafters in an attempt to determine the meaning of ambiguous contract language).

156. Last Will and Testament of Jesse Naputi at 2, In re Estate of Naputi, No. HP07321625 (Cal. Super. Ct. Jul. 19, 2007) (emphasis omitted).

157. Similarly, other testators included a no contest clause in the paragraph immediately after the disinheritance provision. See, e.g., Last Will of Learly Saunders at 2-3, In re Estate of Saunders, No. RP07312533 (Cal. Super. Ct. Aug. 16, 2007). 
intestacy scheme. ${ }^{158}$ However, $122(63.5 \%)$ of them included a no contest provision. ${ }^{159}$ This prophylactic measure seems like overkill in these "all to my spouse" or "to my children equally" wills, which usually sail smoothly through the probate process. Indeed, just nine $(4.7 \%)$ of these estates became embroiled in litigation, compared to twenty-three $(12.4 \%)$ of the other 185 matters, a difference that is statistically significant $(\mathrm{p}<0.01) .{ }^{160}$ Even more to the point, when intestacy-mirroring wills generated a dispute, it was usually initiated by a non-beneficiary who could not have been deterred by a no contest clause. ${ }^{161}$ Therefore, the no contest provisions in these wills were largely superfluous.

At the same time, these clauses had the potential to warp a testator's plans. For one, they could erase the inheritance of a close friend or relation in situations where the testator would have preferred not to inflict such a draconian penalty. Recall that Hite and Burch held that a no contest clause applied to any action that thwarted a testator's intent. ${ }^{162}$ Thus, although the law was hopelessly tangled, a beneficiary gambled with her inheritance if she tried to remove an executor, ${ }^{163}$ object to an accounting, ${ }^{164}$ question whether property belonged to the estate, ${ }^{165}$

158. Because we do not have access to these trusts, we cannot determine whom they ultimately benefit, and therefore we cannot analyze whether the testator followed or deviated from intestacy. Mark Glover's thoughtful response to Boilerplate in Default Rules (in which we also excluded pour over wills from our analysis) raises the issue of whether pour over wills are as likely as conventional wills to contain boilerplate. See Mark Glover, Boilerplate in Pour-over Wills, 103 IOWA L. REV. ONLINE 138, 146 (2018). As a result, we should report that 58 of $72(80.6 \%)$ pour over wills contained a no contest clause, compared to only 248 of $370(67.0 \%)$ conventional wills, which is a statistically significant difference (p < $0.05)$. Otherwise, the actual no contest provisions in pour over wills broke down similarly to their traditional counterparts: 37 (51.4\%) were broad, 13 (18.0\%) were quasi-sophisticated, 3 (3.9\%) were sophisticated, $3(3.9 \%)$ were narrow, and $2(2.8 \%)$ were very broad. The relatively high number of quasi-sophisticated provisions reflects the fact that no contest clauses in pour over wills often cover challenges to the trust into which the will "pours," and our definition of quasi-sophisticated includes attacks on an instrument other than the will.

159. Admittedly, this is a slightly lower percentage of no contest saturation than the wills that deviated from intestacy (126 of 178 , or $70.8 \%$ ).

160. The calculations in this paragraph include the thirteen wills that faced serious validity challenges, which we excluded for the purposes of counting and classifying no contest provisions. Cf. supra text accompanying note 135 . We plugged these instruments into the equation here because we needed to gauge the relationship between a testator's decision to break from the intestacy mold and the incidence of litigation.

161. Learly Saunders's estate is pretty typical. A few of Saunders's grandchildren petitioned to open the case as an intestacy. However, the Public Administrator then successfully moved to admit a will that disinherited them. See Case Summary at 1, In re Estate of Saunders, No. RP07312533 (Cal. Super. Ct. Sept. 10, 2007). Thus, although the case involved litigation, neither the omitted grandchildren nor the Public Administrator would have been subject to a no contest clause in Saunders's will.

162. See supra text accompanying notes 80-88, 121-27; see also In re Kitchen, 220 P. 301,303 (Cal. 1923) (construing an especially capacious no contest clause to "penalize the commencement of any suit whatever").

163. Cf. Estate of Ferber, 77 Cal. Rptr. 2d 774, 780 (Ct. App. 1998) (opining that an exceptionally broad no contest clause that governed "challenges [to] the appointment of any person named as an executor" did not violate public policy as applied to frivolous objections).

164. Cf. id. (holding that the same extremely broad "no contest clause was valid insofar as it prohibited frivolous objections to the accounting, but otherwise was invalid").

165. See Estate of Kazian, 130 Cal. Rptr. 908, 910 (Ct. App. 1976) (finding that beneficiary's attempt to re-characterize assets in the estate as community property "was a proceeding intended to thwart the 
or probate a subsequent will that turned out to be invalid. ${ }^{166}$ It is doubtful that every testator who included a no contest clause meant to wield so heavy a hammer.

In addition, a no contest clause could saddle a beneficiary with hefty costs even if it almost certainly did not govern a particular filing. As the California Law Revision Commission observed in 2007, malpractice-wary lawyers insisted on obtaining declaratory relief from a court that a no contest provision did not apply before doing anything that could possibly violate the provision:

Prudent practitioners now routinely file petitions for declaratory relief under Probate Code $\$ 21320$. Californians now expect to have two levels of litigation when instruments contain a no contest clause: file a Probate Code $\$ 21320$ petition and litigate the declaratory relief, and then litigate the substantive issues in another, separate proceeding. ${ }^{167}$

According to the Executive Committee of the Trusts and Estates Section of the California Bar, this initial round of motion practice cost beneficiaries between $\$ 1,500$ and $\$ 5,000$ in $20 \%$ of cases, $\$ 5,000$ and $\$ 20,000$ in $40 \%$ of cases, $\$ 20,000$ and $\$ 50,000$ in $30 \%$ of cases, and $\$ 50,000$ to $\$ 100,000$ in $10 \%$ of cases. ${ }^{168}$ Thus, no contest clauses could work hardships that most testators probably did not foresee. ${ }^{169}$

Two cases from our dataset illustrate how a no contest clause can become an electric third rail that beneficiaries go out of their way to avoid. First, in 1983, Carrie Troupe executed a will that contained a broad no contest clause that applied to "contests or attacks [on] this Will or any of its provisions." ${ }^{170}$ After she passed away, two beneficiaries accused the executor of serious wrongdoing, including conversion and elder abuse. ${ }^{171}$ Although these allegations did not seem

decedent's wishes as expressed in her will to which the no-contest clause contained in that will properly applied"); see also Estate of Pittman, 73 Cal. Rptr. 2d 622, 628 (Ct. App. 1998) (same result where no contest provision appeared in trust that "meticulously set forth pieces of property to be included in the trust estate and characterized each piece of property as community property").

166. Cf. Estate of Gonzalez, 126 Cal. Rptr. 2d 332, 342 (Ct. App. 2002) (determining that beneficiary violated no contest clause by seeking to validate subsequent will that he obtained by undue influence).

167. Revision of No Contest Clause Statute, 37 CAL. L. REVISION COMM'N REPORTS 359, 386 (2007).

168. Id. at $387 \mathrm{n} .79$.

169. After our research period ended, legislators amended the Probate Code again to "reduce the number of declaratory relief petitions that are being filed with the courts." CAL. SENATE JUDICIARY COMM., BILl ANALYSIS OF S.B. 1264 (Apr. 8, 2008). First, they eliminated the right to seek declaratory relief under section 21320. Johnson v. Greenelsh, 217 P.3d 1194, $1196 \mathrm{n} .2$ (Cal. 2009). Second, they preserved the thrust of section 21305 by declaring that no contest clauses are only enforceable against both "[t]he filing of a creditor's claim" and "[a] pleading to challenge a transfer of property on the grounds that it was not the transferor's property at the time of the transfer" if the provision "expressly [so] provides." Cal. Prob. Code $\S \S 21311(a)(2)-(3)$ (West 2018). Third, they specified that no contest provisions are not enforceable against so-called "direct contests"-petitions that seek to invalidate an instrument under grounds such as forgery, improper execution, incapacity, or undue influence - that are "brought without probable cause." Id. § 21311(a)(1)-(b); id. § 21310(b) (defining "direct contest").

170. Last Will and Testament of Carrie L. Troupe at 2-3, In re Estate of Troupe, No. RP07344385 (Cal. Super. Ct. Oct. 3, 2007).

171. Case Summary, Alameda County Probate Examiners at 1, In re Estate of Troupe, No. RP07344385 (Cal. Super. Ct. Oct. 3, 2007). 
like assaults on the will, the beneficiaries felt compelled to obtain declaratory relief before moving forward with their lawsuit. ${ }^{172}$

Second, an inventor and philanthropist named Kenneth Rainin died in 2007, leaving an estate worth roughly $\$ 600,000,000 .{ }^{173}$ Rainin's trusts made charitable gifts, named his daughter Jennifer beneficiary and co-trustee, and also left a substantial sum to his son, Jesse. ${ }^{174}$ Rainin had also executed a pour over will that contained an expansive no contest clause:

Actions constituting a violation of this paragraph shall include, but shall not be limited to, (1) the filing of a creditor's claim or prosecution of an action based upon it, (2) an action or proceeding to determine the character of property, (3) a challenge to the validity of an instrument, contract, agreement, beneficiary designation or other document relating to my estate plan, and (4) a petition for settlement or for compromise affecting the terms of this Will or any trust .... 175

Unfortunately, several things went sideways during the administration of his estate. For one, Rainin apparently never transferred a huge chunk of his assets to the trust when he was alive, which meant that they needed to pass through probate under the pour over will. Even worse, the trust seemed to make Jesse responsible for paying the entire estate tax bill of more than $\$ 50,000,000 .{ }^{176}$ The attorney who had drafted the trust and all the parties agreed that this was a scrivener's error. ${ }^{177}$ Yet before Jennifer and her co-trustee could try to reform the trust, they needed to devote 180 pages of briefing, declarations, and exhibits to explaining why filing such a petition would not violate the no contest clause in the pour over will. ${ }^{178}$ Therefore, the threat of disinheritance can cause some beneficiaries to seek declaratory relief before doing just about anything related to the testator's estate plan.

In sum, boilerplate no contest clauses can frustrate a testator's intent. How can policymakers increase awareness of these terms? Our next subpart evaluates one potential answer to that question.

172. See id. (noting that the petitioner sought declaratory relief to seek removal of the executor).

173. See Petition for Declaratory Relief Re: No Contest Clause; Memorandum of Points and Authorities at 5, In re Estate of Rainin, No. RP07339583 (Cal. Super. Ct. Oct. 29, 2007) [hereinafter Rainin Petition]; see also Kenneth Rainin, LEGACY.COM (May 6, 2007), https://www.legacy.com/obituaries/sfgate/obituary.aspx?n=kenneth-rainin\&pid=87775077 [https://perma.cc/8QCQ-V3GD].

174. Petition for Instructions; Memorandum of Points and Authorities at 3-4, In re Estate of Rainin, No. RP07339583 (Cal. Super. Ct. Oct. 29, 2007).

175. Rainin Petition, supra note 173, at 5.

176. See Petition to Reform Trust to Effectuate Trustor's Intent; Memorandum of Points and Authorities at 2-6, In re Estate of Rainin, No. RP07339583 (Cal. Super. Ct. Oct. 29, 2007) ("If taxes were paid from [Jesse's] trust, it would completely deplete the value of the trust.").

177. See id. at 5 ("This is a simple matter of a scrivener's error ....").

178. See generally Rainin Petition, supra note 173. Admittedly, because Rainin executed his pour over will in 2002, it was subject to California Probate Code section 21305: the sticky default rule we champion below. The fact that Jennifer sought declaratory relief before taking the uncontroversial step of moving to reform the trust reveals that the statute's specificity requirements do not resolve the uncertainty that swirls around the scope of no contest clauses. 


\section{Sticky Defaults}

As we mentioned above, in the late 1990s, California lawmakers became concerned that courts had opened the door for "generic 'no contest' clauses" to govern a wide range of filings. ${ }^{179}$ In 2001 , the legislature addressed this problem by adopting Probate Code section $21305 .{ }^{180}$ This statute required any testator who wanted a no contest clause to apply to creditor's claims, petitions to re-characterize property, and challenges to other instruments to say so on the face of the will. ${ }^{181}$ As such, it is a classic example of the sticky default rules we urged lawmakers to adopt in Boilerplate and Default Rules. But was it effective? This Subpart reveals that the answer is a qualified yes. Although section 21305 was no miracle cure, wills executed after it came online were less likely to contain a problematic no contest clause.

Comparing pre-2001 wills with their post-2001 counterparts suggests that section 21305 made testators more aware of no contest provisions. First, after the statute became operational, the percentage of wills without a no contest clause increased from $25.7 \%$ to $35.0 \%$, a statistically significant margin $(\mathrm{p}<0.05)$. One could infer that the new law's specificity requirements forced estate planners to discuss no contest clauses in greater depth, which prompted more clients to decide not to include such a provision.

Second, the percentage of wills with broad no contest provisions fell from $56.8 \%$ to $45.3 \%$, which is also statistically significant $(\mathrm{p}<0.05)$. As we noted above, we are especially skeptical of broad clauses, which almost always appear to be lifted wholesale from other sources.

Third, the percentage of wills with sophisticated no contest clauses rose from less than $1.0 \%$ to $4.0 \%$. Although this was not a colossal change, it was statistically meaningful $(\mathrm{p}<0.05)$. In addition, the post-2001 sophisticated clauses were highly individualized. For example, some included petitions to determine title to property, ${ }^{182}$ but others excluded them. ${ }^{183}$ Likewise, testators made their wishes known with respect to disclaimers, ${ }^{184}$ requests for declaratory relief ${ }^{185}$ claims of

179. CAL. Assembly COMM. ON JUdiCiARY, Bill ANALYSis OF A.B. 1491 (Jan. 11. 2000).

180. See supra text accompanying notes $128-29$.

181. See supra text accompanying note 131.

182. See Last Will and Testament of Brian D. Billings at 5, In re Estate of Billings, No. HP07340703 (Cal. Super. Ct. Aug. 15, 2007) (including claims under former Probate Code section 9860, which is now section 850) [hereinafter Billings Will]; Declaration of Brendan P. Cullen in Support of Petitioner's Request for Declaratory Relief, Ex. A at 5-6, In re Estate of Rainin, No. RP07339583 (Cal. Super. Ct. Oct. 29,2007 ) (forbidding beneficiaries from filing "an action or proceeding to determine the character of property") [hereinafter Rainin Will].

183. See Last Will of Carlos Q. Luciano at 5, In re Estate of Luciano, No. RP08364463 (Cal. Super. Ct. Jan. 7, 2008) ("I specifically exempt petitions under California Probate code Section[] 9860 ....") [hereinafter Luciano Will].

184. See Will of Clement F. Burnap at 7-8, In re Estate of Burnap, No. RP07311074 (Cal. Super. Ct. Feb. 14, 2007) ("The provisions of this paragraph shall not apply to any disclaimer.").

185. See Luciano Will, supra note 183, at 5 (carving out claims under Probate Code section 17200, which allows trust beneficiaries to petition the probate court for instructions regarding a variety of issues). 
common law marriage, ${ }^{186}$ actions for "a community property set aside, constructive trust, quiet title ... or contract to make a will," 187 and "challenge[s] to the validity of an instrument, contract, or agreement, beneficiary designation, or other document related to my estate plan." 188 This customized language is a far cry from the rote repetition of boilerplate.

Table 2: No Contest Clauses By Date of Will Execution

\begin{tabular}{|c|c|c|c|c|}
\hline & \multicolumn{2}{|c|}{ Before 2001} & \multicolumn{2}{|c|}{ After 2001} \\
\hline & $\mathrm{N}$ & Percent & $\mathrm{N}$ & Percent \\
\hline Broad & 121 & $56.8 \%$ & 102 & $\begin{array}{l}45.1 \% * \dagger \\
(p=0.02)\end{array}$ \\
\hline None & 55 & $25.7 \%$ & 80 & $\begin{array}{l}35.2 \% * \dagger \\
(p=0.04)\end{array}$ \\
\hline Quasi-Sophisticated & 17 & $8.0 \%$ & 10 & $\begin{array}{l}4.4 \% \dagger \dagger \\
(p=0.16)\end{array}$ \\
\hline Very Broad & 8 & $3.7 \%$ & 18 & $\begin{array}{l}8.0 \% \dagger \dagger \\
(p=0.07)\end{array}$ \\
\hline Narrow & 11 & $5.1 \%$ & 7 & $\begin{array}{l}3.1 \% \dagger \dagger \\
(p=0.34)\end{array}$ \\
\hline Sophisticated & 1 & $<1.0 \%$ & 9 & $\begin{array}{l}4.0 \% *+\dagger \\
(p=0.02)\end{array}$ \\
\hline Total & 213 & $100 \%$ & 226 & $100 \%$ \\
\hline
\end{tabular}

Notes:

This Table excludes one will that is missing a date as well as the two wills with missing pages.

$\dagger$ Z-tests compare the proportion of wills with each type of clause that were executed before 2001 with those that were executed afterwards.

186. See Will of Lois Rita Wheelock at 3, In re Estate of Wheelock, No. RP08393246 (Cal. Super. Ct. Jun. 17, 2008) (noting that no contest provision applies to those challenging will on common law marriage grounds).

187. See Billings Will, supra note 182, at 5 (covering petitions for "a community property set aside, constructive trust, [or] quiet title").

188. Rainin Will, supra note 182, at 5. 
$\dagger \dagger$ Fisher's exact tests compare the proportion of wills with each type of clause that were executed before 2001 with those that were executed afterwards.

$* \mathrm{p}<0.05, * * \mathrm{p}<0.01, * * * \mathrm{p}<0.001$

Fourth, the percentage of wills that contained seemingly unnecessary no contest clauses fell sharply after section 21305 kicked in. As noted above, we are distrustful of no contest provisions in wills that roughly track the intestacy statute. ${ }^{189}$ For ease of reference, we will call these "suspected boilerplate" no contest clauses. Before 2001, 43.4\% of wills in our sample contained suspected boilerplate no contest provisions; afterwards, this figure dropped to just $20.8 \%$ ( $\mathrm{p}<$ 0.001 ). Of course, this might be nothing more than a shadow cast by the fact that the total number of no contest clauses also declined. Thus, to slice the data another way, we also examined whether the percentage of suspected boilerplate provisions also changed in the narrower universe of wills that contain no contest clauses. We found that suspected boilerplate accounted for $59.8 \%$ of all no contest provisions before section 21305 , but just $33.9 \%$ afterwards $(\mathrm{p}<0.001)$.

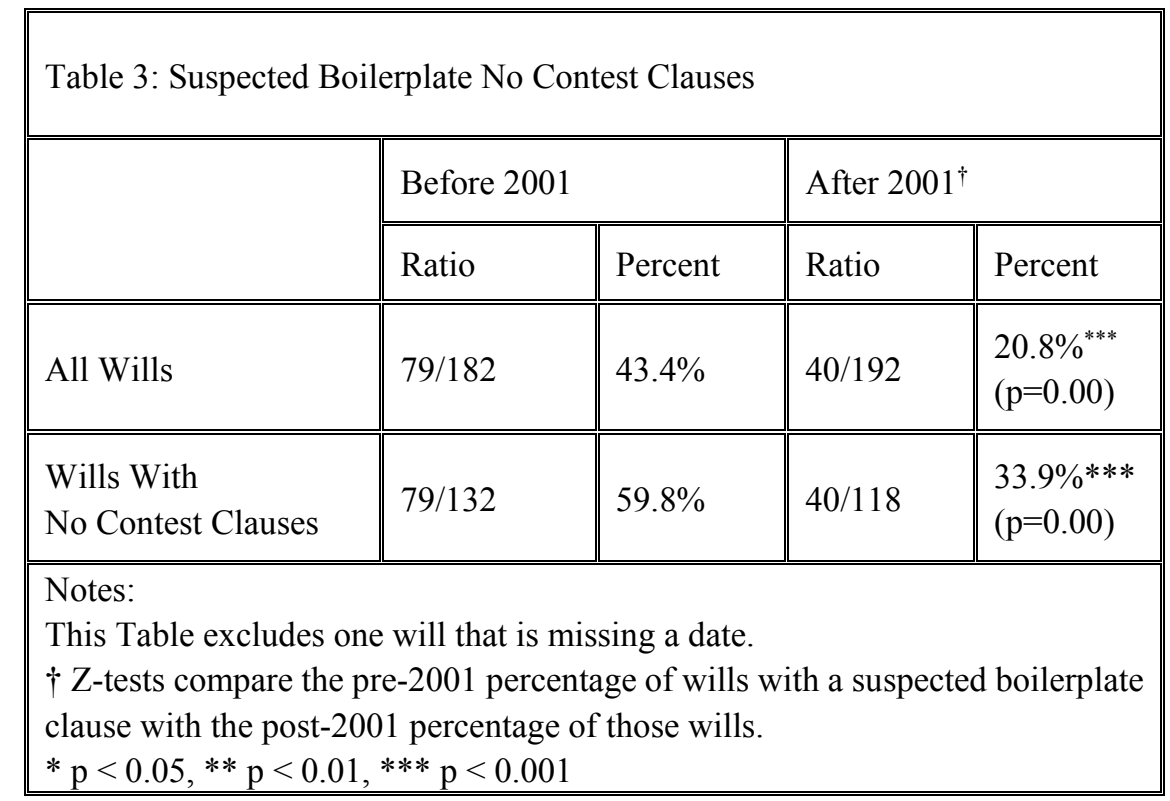

Finally, a logit regression also suggests that the new statute was correlated with a drop in unnecessary no contest clauses. We used the existence of a suspected boilerplate no contest clause as our dependent variable. Our independent variables included whether a case was filed in Oakland versus the other Alameda County courthouses that handled probate matters during this time, the testator's gender, whether the testator was married when she executed the will, whether

189. See supra text accompanying notes $158-62$. 
the testator was married when she died, the gross value of the estate, the gross value of the estate's real property, whether the will contains a just debts clause, and whether the will was drafted by the testator herself. ${ }^{190}$ As Table 4 reveals, the odds of a will containing a boilerplate no contest clause are $57.2 \%$ lower after the statute's enactment. Likewise, in the sample of wills with no contest provisions, the odds that a will's no contest clause would be boilerplate fell by $61.6 \% .{ }^{191}$

\begin{tabular}{|c|c|c|}
\hline \multicolumn{3}{|c|}{$\begin{array}{l}\text { Table 4: Regression Analysis } \\
\text { Outcome Variable: Suspected Boilerplate No Contest Clause } \\
\text { (Standard Errors) } \\
\text { [Odds Ratio] } \\
\end{array}$} \\
\hline & $\begin{array}{l}\text { Column 1: } \\
\text { All Wills }\end{array}$ & $\begin{array}{l}\text { Column 2: } \\
\text { Wills With } \\
\text { No Contest } \\
\text { Clauses }\end{array}$ \\
\hline Will Executed After 2001 & $\begin{array}{l}-0.848 * * * \\
(0.252) \\
{[0.428]}\end{array}$ & $\begin{array}{l}-1.035^{* * *} \\
(0.287) \\
{[0.355]}\end{array}$ \\
\hline Estate Filed in Oakland & $\begin{array}{l}-0.648 * * \\
(0.250) \\
{[0.523]}\end{array}$ & $\begin{array}{l}-0.600^{*} \\
(0.291) \\
{[0.549]}\end{array}$ \\
\hline
\end{tabular}

190. There are four kinds of self-made wills in our sample: holographs, documents that the testator either handwrote or typed herself and then had witnessed, fill-in-the-blank forms, and instruments created through software sold by Nolo Press or LegalZoom.

191. In the sample of all wills, the logit coefficient for the "Will Executed after 2001" variable is statistically significant $(\mathrm{p}=0.001)$ and the odds ratio is 0.428 , which suggests that the odds of a will containing a boilerplate no contest clause are $57.2 \%$ lower $(1-0.428=0.572)$ after the statute's enactment. In the sample of wills with no contest provisions, the logit coefficient on "Will Executed after 2001" is statistically significant $(\mathrm{p}<0.001)$ and the odds ratio is 0.355 , which implies that the odds that a will's no contest clause would be boilerplate fell by $64.5 \%(1-0.355=0.645)$.

A few other variables were also correlated in a statistically significant fashion with the odds of finding a boilerplate no contest provision. First, estates filed in Oakland were less likely to include such a provision in both the larger sample of all wills and the subsample of wills that contain no contest clauses. We are unsure why this might be. Second, the fact that the testator was married when she executed the will made it more likely that a will would contain a boilerplate no contest provision in both samples. Our best guess is that this reflects the fact that married testators generally give their entire estate to their spouse and thus are less likely to sharply deviate from intestacy. In turn, this means that married testators' no contest clauses are probably going to be "suspected boilerplate" as we define it. Third, the odds are lower that a self-made will features a boilerplate no contest clause. This makes sense, because holographs and their ilk usually do not feature no contest clauses, period. But cf. supra text accompanying notes 15052. Somewhat paradoxically, in the sample of wills that contain no contest clauses, the fact that a will is self-drafted increases the odds of finding a boilerplate no contest provision. As with married testators, we think the culprit is that self-made wills tend to follow intestacy; thus, any no contest clause in a do-ityourself instrument is going to be "suspected boilerplate" (or, more accurately, "generally unnecessary"). 


\begin{tabular}{|c|c|c|}
\hline Female Testator & $\begin{array}{l}-0.233 \\
(0.249) \\
{[0.792]}\end{array}$ & $\begin{array}{l}-0.091 \\
(0.286) \\
{[0.913]}\end{array}$ \\
\hline $\begin{array}{l}\text { Testator Married } \\
\text { When Will Executed }\end{array}$ & $\begin{array}{l}0.681^{*} \\
(0.316) \\
{[1.977]}\end{array}$ & $\begin{array}{l}1.037 * * \\
(0.387) \\
{[2.821]}\end{array}$ \\
\hline Testator Married at Death & $\begin{array}{l}-0.392 \\
(0.481) \\
{[0.676]}\end{array}$ & $\begin{array}{l}-0.579 \\
(0.565) \\
{[0.561]}\end{array}$ \\
\hline $\begin{array}{l}\text { Gross Estate Value } \\
\text { (In Hundreds of Thousands) }\end{array}$ & $\begin{array}{l}-0.322 \\
(0.392) \\
{[0.725]}\end{array}$ & $\begin{array}{l}-0.456 \\
(0.463) \\
{[0.634]}\end{array}$ \\
\hline $\begin{array}{l}\text { Gross Real Property Value } \\
\text { (In Hundreds of Thousands) }\end{array}$ & $\begin{array}{l}0.064 \\
(0.047) \\
{[1.066]}\end{array}$ & $\begin{array}{l}0.056 \\
(0.054) \\
{[1.058]}\end{array}$ \\
\hline Just Debts Clause & $\begin{array}{l}0.207 \\
(0.253) \\
{[1.230]}\end{array}$ & $\begin{array}{l}-0.012 \\
(0.292) \\
{[0.988]}\end{array}$ \\
\hline Self-Drafted Will & $\begin{array}{l}-0.751 * \\
(0.342) \\
{[0.472]}\end{array}$ & $\begin{array}{l}1.042 * \\
(0.505) \\
{[2.834]}\end{array}$ \\
\hline Constant & $\begin{array}{l}0.030 \\
(0.326)\end{array}$ & $\begin{array}{l}0.569 \\
(0.376)\end{array}$ \\
\hline $\mathrm{N}$ & 372 & 249 \\
\hline \multicolumn{3}{|c|}{$\begin{array}{l}\text { Notes: } \\
\text { The regression sample sizes are smaller than the overall samples be- } \\
\text { cause some cases are missing data. } \\
* \mathrm{p}<0.05, * * \mathrm{p}<0.01, * * * \mathrm{p}<0.001\end{array}$} \\
\hline
\end{tabular}

Admittedly, our research also reveals some downsides of sticky default rules. One critique of magic words mandates like section 21305 is that instead of sparking discussion between lawyers and clients, they simply breed new boilerplate that bears the magic words. ${ }^{192}$ There are some glimmers of this phenomenon in

192. See Weisbord \& Horton, supra note 10, at 706 ("Sticky defaults also increase the risk of ambiguity about a testator's desires.”). 
our data. For example, June Wagner's will disinherits anyone who files a creditor's claim, a petition to determine the character of property, or "[a] challenge to any beneficiary designation, or any joint title on any account." ${ }^{193}$ However, this ostensibly sophisticated no contest clause appears under the caption "Nomination and Authority of Executor" 194 - a typo that indicates that nobody read this part of the document closely.

Likewise, a series of wills written by the same lawyers complicates our happy story. Our pre-2001 data features five wills from a small law office, and each contains an identical broad no contest provision. Our post-2001 sample contains two wills from this firm, and each boasts the exact same sophisticated clause. This symmetry suggests that even if section 21305 altered the content of no contest clauses, it may have only led drafters to trade one strain of boilerplate for another. ${ }^{195}$

193. Will of June Wagner at 4, In re Estate of Wagner, No. RP07340300 (Cal. Super. Ct. Aug. 13, 2007).

194. Id.

195. An eagle-eyed reader who examines Figures 2 and 3 closely will notice an additional complication: at some point around 2001, the original lawyer's son apparently took over the practice. Thus, the new language in the wills could also reflect this passing of the baton. 
Figure 2: Pre-2001 No Contest Clause

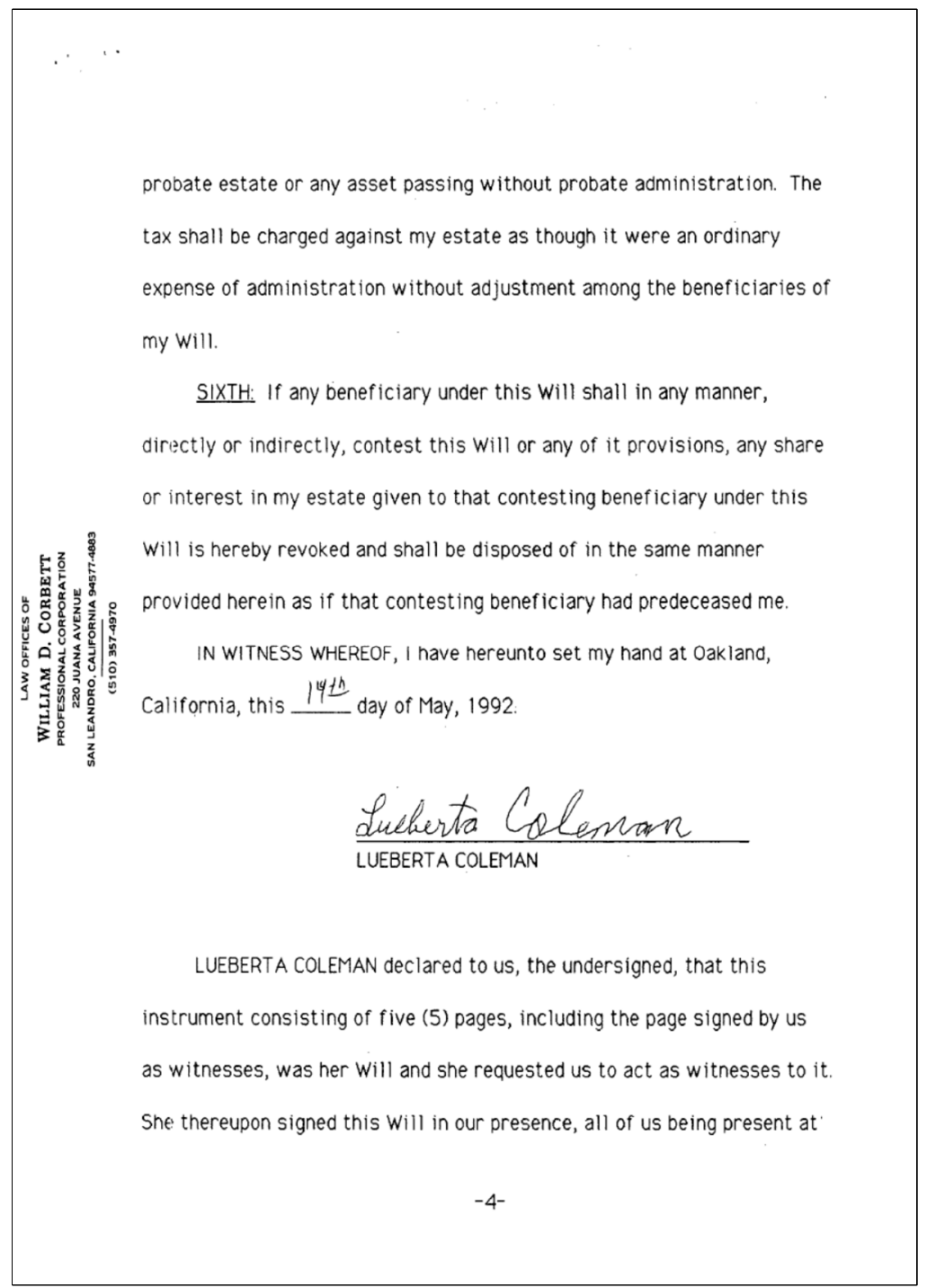


Figure 3: Post-2001 No Contest Clause

it were an ordinary expense of administration without adjustment among the beneficiaries of my Will.

SIXTH: If any beneficiary under this Will shall in any manner, directly or indirectly, contest this Will or any of its provisions, any share or interest in my estate given to that contesting beneficiary under this Will is hereby revoked and shall be disposed of in the same manner provided herein as if that contesting beneficiary had

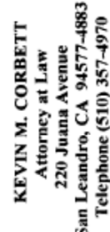
predeceased me. Actions which shall constitute a contest of this Will shall include, but not be limited to the following: a) the filing of a creditor's claim or prosecution of an action based upon it; b) any action or proceeding to determine the character of property; c) any petition or action for settlement or for compromise affecting the terms of this Will; d) any challenge to the validity of any trust instrument executed by me at any time, or any of the provisions thereof; e) any petition or action for order for payment of family allowance; f) any petition or action for order setting aside exempt property; g) any petition or action for order setting aside probate 
homestead; and h) any petition, proceeding or any other action whatsoever which seeks to alter, amend or change in any manner or fashion the exact distribution plan stated in this Will or in any trust instrument executed by me at any time. It is my intent herein that any attempt to alter, amend or change in any way the exact distribution plan stated in this Will or in any trust instrument executed by me at any time or any attempt to cause any portion of my estate to be

distributed in any way other than as stated by me in this Will or in any trust instrument executed by me at any time, is to be considered a contest of this Will and any person taking such action is to be considered a contestant of this Will.

IN WITNESS WHEREOF, I have hereunto set my hand at San Leandro, California, this 14th day of June, 2002.

\section{EVELINE G. B. NOYES}

EVELINE G. B. NOYES declared to us, the undersigned, that this instrument consisting of five (5) pages, including the page signed $-4-$

To summarize, our research suggests that sticky defaults can reduce the incidence of intent-defeating boilerplate. In Alameda County, the passage of section 21305 was correlated with fewer vague, open-ended prohibitions on attacking a will or its provisions. Although the statute did not eliminate form language completely, it seems to have made testators and their attorneys more attune to the complexities of a clause that has great advantages but also tremendous potential for unexpected and unjust outcomes. 


\section{$\mathrm{V}$ \\ CONCLUSION}

Boilerplate in wills is a complex phenomenon. It is quick and cheap to insert, and it can ride the wake of multiple judicial opinions that clarify its meaning. But form terms can also become so routine that lawyers forget to ask whether they suit a client's needs. No contest clauses in Alameda County seem to have acquired this perverse momentum: they appear in a super-majority of wills even though their costs often seem to outweigh their benefits.

Although there is no magic bullet solution to intent-defeating boilerplate, sticky default rules have two advantages. First, by making it hard for testators to opt out, they insulate favorable default rules from the careless use of stock language. Indeed, under a sticky default, boilerplate that once displaced a majoritarian principle no longer suffices, meaning that fewer testators will have their intent thwarted. Second, as our research implies, sticky defaults can shine light on previously non-salient terms. By demanding extra time and attention during the drafting process, sticky defaults can foster discussions between lawyers and clients and encourage thoughtful estate planning. Accordingly, sticky defaults can help reverse the harm caused by intent-defeating boilerplate, especially in the area of no contest clauses. 